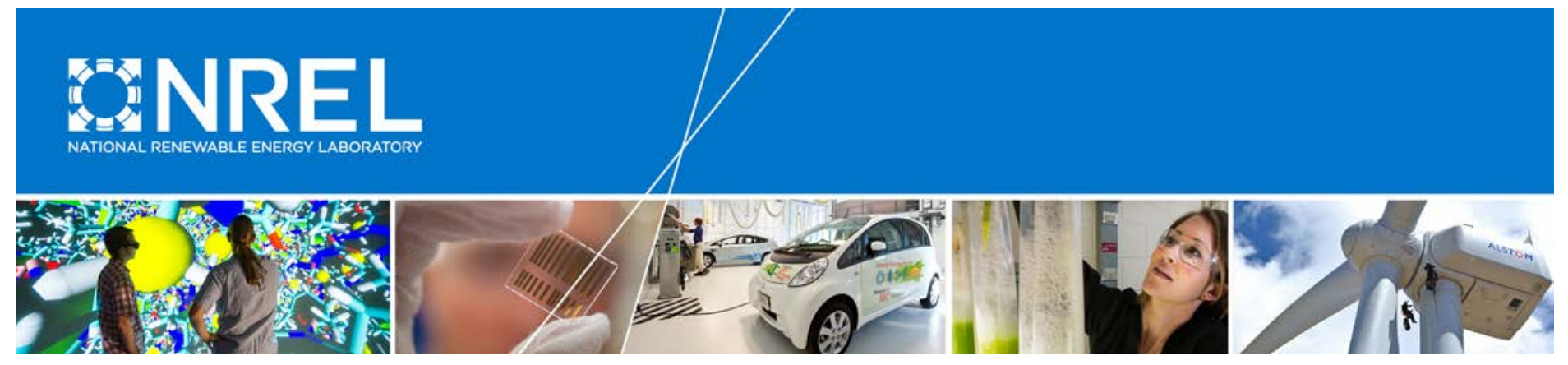

\title{
Guide to Permitting Hydrogen Motor Fuel Dispensing Facilities
}

Carl Rivkin, William Buttner, and Robert Burgess National Renewable Energy Laboratory

NREL is a national laboratory of the U.S. Department of Energy Office of Energy Efficiency \& Renewable Energy Operated by the Alliance for Sustainable Energy, LLC

This report is available at no cost from the National Renewable Energy Laboratory (NREL) at www.nrel.gov/publications.

Technical Report

NREL/TP- 5400-64042

March 2016

Contract No. DE-AC36-08G028308 


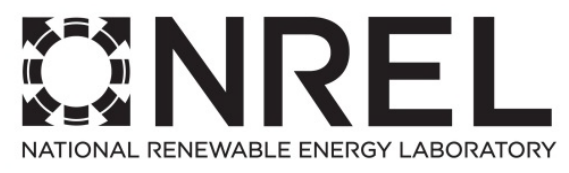

\section{Guide to Permitting Hydrogen Motor Fuel Dispensing Facilities}

Carl Rivkin, William Buttner, and Robert Burgess National Renewable Energy Laboratory

Prepared under Task No. HT12.7310

NREL is a national laboratory of the U.S. Department of Energy Office of Energy Efficiency \& Renewable Energy Operated by the Alliance for Sustainable Energy, LLC

This report is available at no cost from the National Renewable Energy Laboratory (NREL) at www.nrel.gov/publications.

National Renewable Energy Laboratory 15013 Denver West Parkway Golden, CO 80401 303-275-3000 • www.nrel.gov

\section{Technical Report} NREL/TP- 5400-64042

March 2016

Contract No. DE-AC36-08GO28308 


\section{NOTICE}

This report was prepared as an account of work sponsored by an agency of the United States government. Neither the United States government nor any agency thereof, nor any of their employees, makes any warranty, express or implied, or assumes any legal liability or responsibility for the accuracy, completeness, or usefulness of any information, apparatus, product, or process disclosed, or represents that its use would not infringe privately owned rights. Reference herein to any specific commercial product, process, or service by trade name, trademark, manufacturer, or otherwise does not necessarily constitute or imply its endorsement, recommendation, or favoring by the United States government or any agency thereof. The views and opinions of authors expressed herein do not necessarily state or reflect those of the United States government or any agency thereof.

This report is available at no cost from the National Renewable Energy Laboratory (NREL) at www.nrel.gov/publications.

Available electronically at SciTech Connect http:/www.osti.gov/scitech

Available for a processing fee to U.S. Department of Energy and its contractors, in paper, from:

U.S. Department of Energy

Office of Scientific and Technical Information

P.O. Box 62

Oak Ridge, TN 37831-0062

OSTI http://www.osti.gov

Phone: 865.576.8401

Fax: 865.576.5728

Email: reports@osti.gov

Available for sale to the public, in paper, from:

U.S. Department of Commerce

National Technical Information Service

5301 Shawnee Road

Alexandria, VA 22312

NTIS http://www.ntis.gov

Phone: 800.553 .6847 or 703.605 .6000

Fax: 703.605.6900

Email: orders@ntis.gov 


\section{Acknowledgments}

NREL would like to recognize the valuable technical input of Karen Hall of the Fuel Cell and Hydrogen Energy Association and Jennifer Hamilton of the California Fuel Cell Partnership who acted as reviewers of this document. They provided valuable input and many recommendations that greatly improved the document.

Funding for this work is provided by the U.S. Department of Energy Fuel Cell Technologies Office within the Office of Energy Efficiency and Renewable Energy. 


\section{Table of Contents}

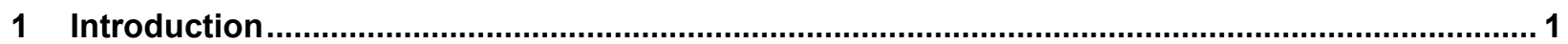

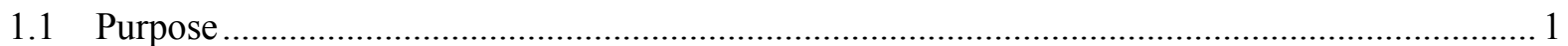

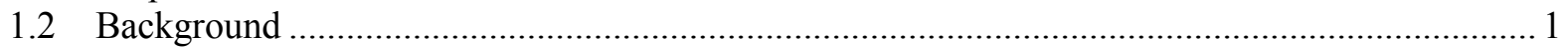

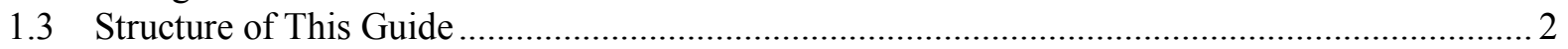

2 Hydrogen Motor Fuel Dispensing Facility Basics .................................................................. 3

3 Hydrogen Motor Fuel Dispensing Facility Requirements ....................................................... 4

3.1 Construction Requirements for Gaseous Hydrogen Storage ..................................................... 4

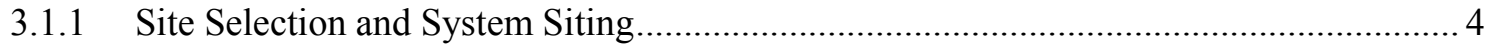

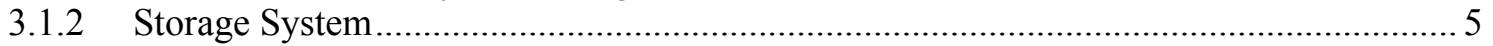

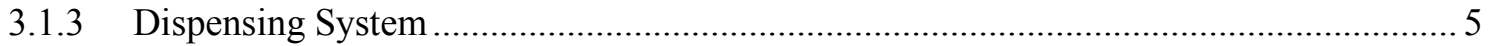

3.2 Construction Requirements for Liquefied Hydrogen Storage .................................................. 5

3.3 Operating Requirements for a Hydrogen Motor Fuel Dispensing Facility ............................... 6

4 Codes and Standards Affecting Design, Installation, and Operation of a Hydrogen Motor Fuel

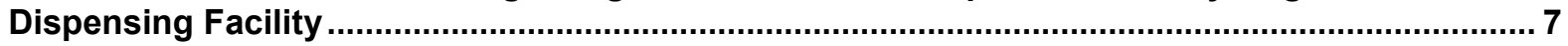

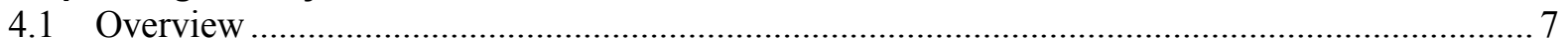

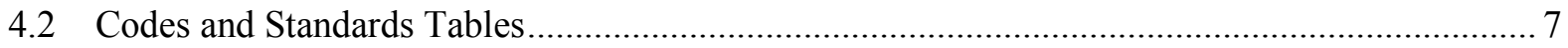

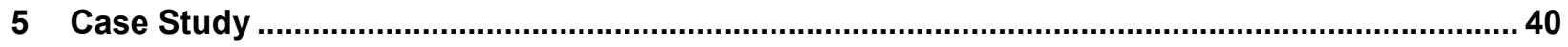

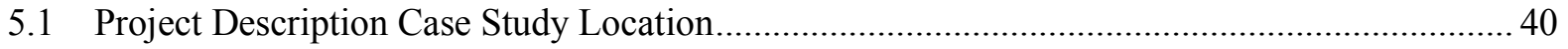

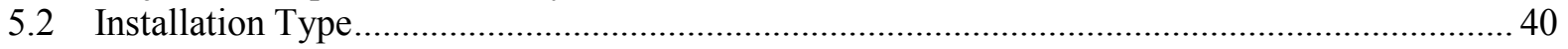

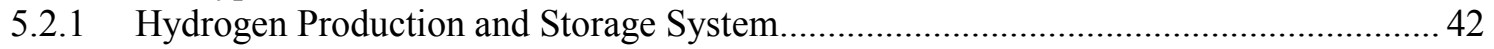

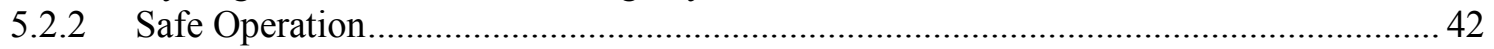

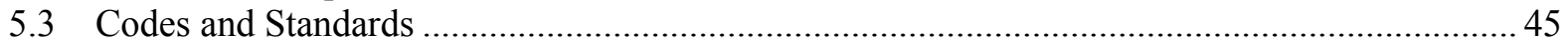

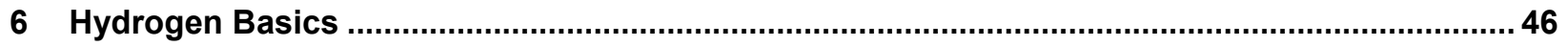

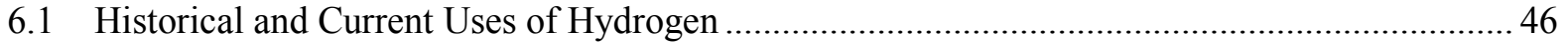

6.2 Hydrogen: Similarities to and Differences from Other Common Fuels................................... 46

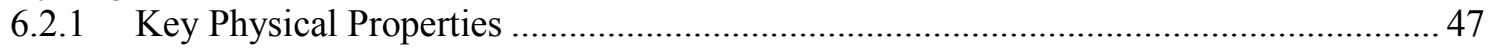

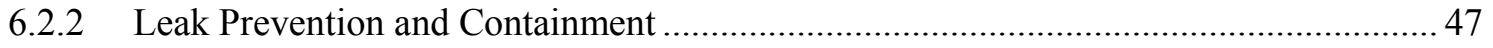

6.2.3 Key Properties of Hydrogen Relating to Fires and Explosions.................................. 48

7 Glossary 


\section{List of Tables}

Table 1. Applicable Codes and Standards ........................................................................................ 7

Table 2. Codes and Standards for Hydrogen Motor Fuel Dispensing Facilities...................................... 12

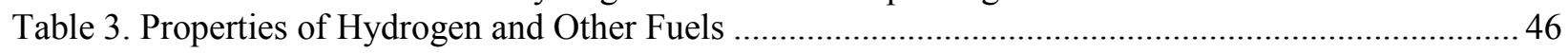

\section{List of Figures}

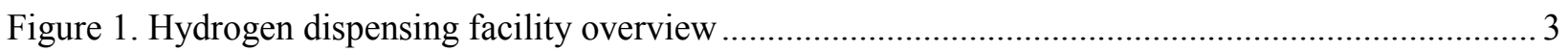

Figure 2. NREL hydrogen fueling facility systems control monitoring screen .................................... 41

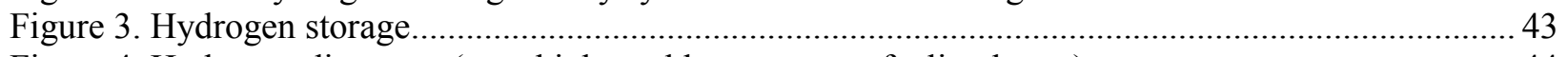

Figure 4. Hydrogen dispenser (note high- and low-pressure fueling hoses) .......................................... 44 


\section{Introduction}

\subsection{Purpose}

The purpose of this guide is to assist project developers, permitting officials, code enforcement officials, and other parties involved in developing permit applications and approving the implementation of hydrogen motor fuel dispensing facilities. The guide facilitates the identification of:

- The elements to be addressed in the permitting of a project as it progresses through the approval process

- The specific requirements associated with those elements

- The applicable (or potentially applicable) codes and standards by which to determine whether the specific requirements have been met.

In this guide, a hydrogen motor fuel dispensing facility is a service station for:

1. Receiving hydrogen produced off-site and delivered to the station or producing hydrogen on-site

2. Long-term storage of liquid hydrogen or compressed hydrogen gas or both

3. Dispensing hydrogen to fuel cell vehicles and vehicles with hydrogen-powered internal combustion engines. Such a facility is analogous to a gasoline service station but stores and dispenses hydrogen (instead of gasoline and diesel fuel) to cars, buses, and trucks.

The guide attempts to identify all applicable codes and standards relevant to the permitting requirements. Consequently, the codes and standards articulated include:

- International Code Council (ICC)

- National Fire Protection Association (NFPA)

- American Society of Mechanical Engineers (ASME)

- Compressed Gas Association (CGA).

\subsection{Background}

Widespread deployment of hydrogen fuel cell vehicles requires hydrogen fueling stations. Just as there currently are corner gasoline stations, there will be a need for corner hydrogen fueling stations (or stations that provide both gasoline and hydrogen).

In the United States, only a small number of public hydrogen fueling stations currently exist. Most were established to support demonstration or experimental hydrogen-powered vehicle projects. Because these stations are first-of-a-kind, there is not a commodity-style standard station design.

However, as automakers gear up to market fuel cell vehicles to American consumers (both to individuals and to fleet vehicle operators), the hydrogen and petroleum industries are gearing up to construct hydrogen fueling stations to service these vehicles. 
As hydrogen fueling station projects are proposed, the building code and fire safety officials permitting them will require a good understanding of the issues that must be considered and the codes and standards that should be applied in the permitting process.

\subsection{Structure of This Guide}

Section 2 provides a brief description of the basic installation of a stationary hydrogen motor fuel dispensing station that receives and stores liquid hydrogen, vaporizes the hydrogen and compresses it, and then dispenses hydrogen gas into vehicles.

Section 3 presents an overview of the safety requirements that a hydrogen motor fuel dispensing facility should meet, based on the lessons learned and experience gained from existing projects.

Section 4 provides the requirements for the systems, components, and other entities that a hydrogen motor fuel dispensing station comprises. The information is intended to help enforcement officials develop permit conditions specifically for a hydrogen fueling facility.

Section 5 presents a case study with detailed but non-technical descriptions of a representative hydrogen motor fuel dispensing facility already in operation in the United States.

Section 6 describes the historic and current uses of hydrogen fuel and its similarities to and differences from other common fuels including gasoline, propane, and natural gas.

Section 7 is a glossary of terms that are commonly used with hydrogen technologies and the associated codes and standards. 


\section{Hydrogen Motor Fuel Dispensing Facility Basics}

Figure 1 shows the basic installation of a stationary hydrogen motor fuel dispensing facility that receives and stores liquid hydrogen, vaporizes the hydrogen and compresses it, and then dispenses hydrogen gas into vehicles at 5,000 to 10,000 psi (350 to 700 bar). The basic elements of the installation include liquid hydrogen storage tanks (liquid hydrogen delivered to the site); cryogenic hydrogen compressors for high-pressure hydrogen supply; vaporizers; and gaseous high-pressure storage tanks.

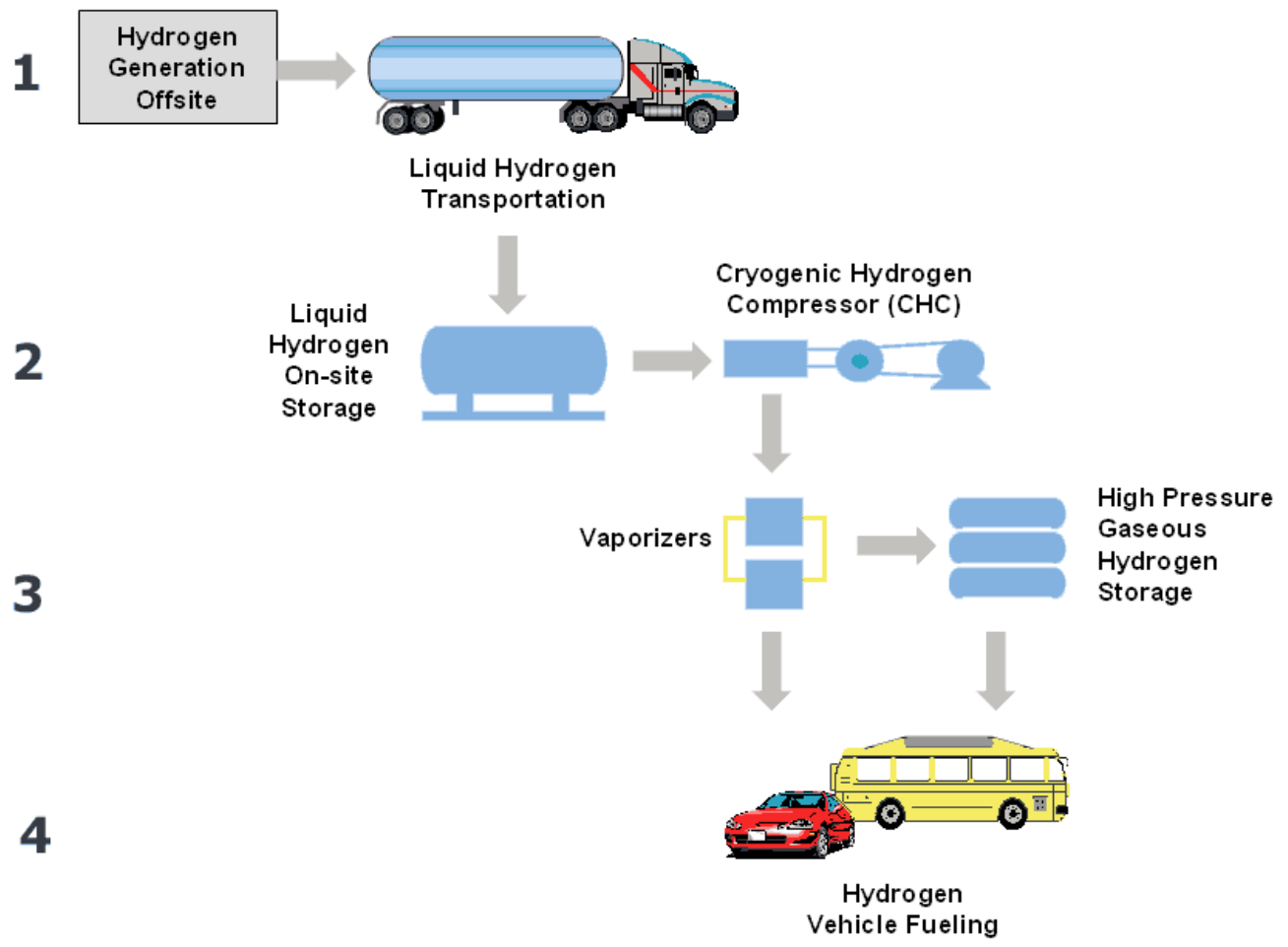

Figure 1. Hydrogen dispensing facility overview

For hydrogen fueling to take place, several steps are required:

1. The hydrogen must be transported to the fueling station or generated on-site.

2. The hydrogen is stored on-site. The hydrogen can be stored as either a gas or liquid on the dispensing facility site.

3. The hydrogen is converted to its final form. The storage of the hydrogen may be in a different form than required for the dispensing into the vehicle. In the case study included in Section 5, the fuel is converted from liquid to gas for final distribution to the vehicles.

4. The hydrogen is dispensed into the vehicle. 


\section{Hydrogen Motor Fuel Dispensing Facility Requirements}

The basic system components and the requirements that would apply to facilities for dispensing hydrogen motor fuel are summarized in this section. Three objectives underlie the various safety requirements described:

1. To reduce the probability of a release of hydrogen

2. To reduce the probability of an accident if there were a release

3. To reduce the severity of an accident if one were to occur.

Component and system materials requirements and piping requirements prevent unintended hydrogen releases. System separation distance requirements reduce the probability and severity of accidents.

For construction permitting, the requirements are organized so that they follow the chronological order of events involved in constructing a facility. The requirements for an operating permit are organized to follow, to the extent possible, the flow of hydrogen (whether as a liquid or gas) through the fueling process.

This organizational structure may not match the sequence for inspecting the system components. The same requirements are not listed in both the construction and operating sections. For example, the electrical requirements for classified areas would be found under the construction requirements. The same requirements would apply for a new facility as for a retrofitted facility.

The schematic in Figure 1 for a generic dispensing facility includes both liquid hydrogen storage and gaseous hydrogen storage. Because the density of gaseous hydrogen is low, many stations to be constructed in the near term will include both liquid and gaseous storage.

\subsection{Construction Requirements for Gaseous Hydrogen Storage}

Construction requirements for hydrogen motor fuel dispensing facilities fall into one of three categories:

1. Site selection and system siting

2. Storage system (including compression)

3. Dispensing system.

\subsubsection{Site Selection and System Siting}

Requirements for system siting should include a review of zoning requirements, review of the method for transport of hydrogen to the site, and review of the method for transfer of hydrogen from a transport vehicle or pipeline to the site storage system. Because hydrogen is classified as a hazardous material by the U.S. Department of Transportation (DOT), hazardous material storage and transportation requirements will apply. Hydrogen will be transported to the site, so there must be a route to the site that does not restrict hydrogen shipment. 
It is also very important that prospective permit applicants meet with enforcement officials as soon as possible to address any special concerns relating to the proposed project location.

There also must be sufficient room at the site for a truck or other vehicle to unload. Buildings at the site must be positioned so that separation distance requirements are met.

\subsubsection{Storage System}

The storage system consists of five types of components:

- Storage container

- Connectors

- Piping

- Vents

- Controlling devices.

Examples of controlling devices include regulators to control volumetric flow rate in piping and ventilation for systems located inside buildings. All five of these component types are addressed in NFPA 55: Compressed Gases and Cryogenic Fluids Code, the International Fire Code (IFC), the International Fuel Gas Code (IFGC), and NFPA 2: Hydrogen Technologies Code.

\subsubsection{Dispensing System}

The IFC has generic requirements for hydrogen and motor fuel dispensing, while the 2016 edition of NFPA 2: Hydrogen Technologies Code gives detailed requirements for hydrogen dispensing. Most jurisdictions in the United States use the IFC as opposed to NFPA 1 Uniform Fire Code. However, between the two codes almost all jurisdictions in the United States are covered by a fire code.

All components for the dispensing system must be listed or approved for use with hydrogen, and any electrical equipment in the dispensing area must meet the requirements of the National Electric Code. The 2014 edition of NFPA 497: Recommended Practice for the Classification of Flammable Liquids, Gases, or Vapors and of Hazardous (Classified) Locations for Electrical Installations in Chemical Process Areas gives guidance on determining the electrical classification for an area and what equipment must be used in the area. NFPA 2: Hydrogen Technologies Code provides requirements for electrical classification around the dispenser.

Safety interlocks are an important part of the dispensing system. The system must be constructed so that it will shut down to prevent overfilling or in the event of an accidental release. The systems are constructed so that if a release is detected from a hydrogen gas sensor or a pressure sensor the system will stop the flow of hydrogen and prevent large releases.

\subsection{Construction Requirements for Liquefied Hydrogen Storage}

Both the IFC and the 2013 edition of NFPA 55: Compressed Gases and Cryogenic Fluids Code give requirements for a liquefied hydrogen storage system. 
The construction requirements for a liquefied hydrogen storage system are similar to those for a gaseous hydrogen storage system. However, because the density of liquid hydrogen is so much greater than that of gaseous hydrogen, the separation distances between liquid hydrogen storage systems and exposures are much larger. For example, based on NFPA 55, a gaseous storage system of 12,000 psig storage pressure must be at least 14 feet from an adjacent structure not having a sprinkler system, while for a liquid system this separation distance would have to be 75 feet.

\subsection{Operating Requirements for a Hydrogen Motor Fuel Dispensing Facility}

Typically, after a construction permit is issued defining construction conditions, an operating permit — which articulates conditions for safe operation - is issued to allow the facility to operate. The conditions of the operating permit will also contain requirements for data collection and recordkeeping to give the inspector information to show that the facility has been operating safely on an ongoing basis. This information could be in the form of maintenance records, worker training records, operational data such as system pressure readings, or other information to show that the facility is meeting the safety conditions in its permit.

Operational safety has several elements. They can include:

1. An emergency response plan

2. Written operating procedures

3. Staff training

4. Equipment maintenance

5. Ongoing documentation of safety checks

6. Compliance records.

An emergency response plan is required because a facility must operate safely in routine and upset conditions. Written operating procedures help operating personnel perform tasks correctly and consistently, according to established standards. It is important that different workers not perform operations differently. These variations increase the probability of accidents and reduce the system reliability.

Staff training, reinforced by written operating procedures, is the means to ensure that operating personnel perform tasks correctly. It is important that staff be involved in developing and modifying operating procedures to ensure that they are usable. Equipment must be maintained according to the manufacturers' recommendations, and maintenance and safety checks must be documented.

Compliance records demonstrate the safe operating history of the equipment. These records are particularly important in the event of any incident that requires a safety investigation. 


\section{Codes and Standards Affecting Design, Installation, and Operation of a Hydrogen Motor Fuel Dispensing Facility}

\subsection{Overview}

This section addresses the codes and standards that affect the design, installation, and operation of a hydrogen motor fuel dispensing facility and will therefore have an impact on its suitability for service to the public. The purpose of this section is to provide regulators, manufacturers, and designers some insight into the requirements that will need to be satisfied to deploy the technology and to provide code officials with a focus on the issues and criteria that will be relevant to them in considering and approving the technology.

\subsection{Codes and Standards Tables}

The applicable codes and standards identified in Table 1 provide a general guide to the regulations affecting the design of hydrogen motor fuel dispensing stations. More detail on the exact provisions for specific issues is provided in Table 2.

Table 1. Applicable Codes and Standards

\begin{tabular}{|l|l|}
\hline Title of Code/Standard & Contact \\
\hline $\begin{array}{l}\text { ASME Boiler and Pressure Vessel Code (BPVC) } \\
\text { Establishes rules of safety governing the design, fabrication, and inspection of boilers, } \\
\text { pressure vessels, and nuclear power plant components during construction. }\end{array}$ & ASME \\
\hline $\begin{array}{l}\text { ASME B31.12 (2012) Hydrogen Piping and Pipelines } \\
\text { This code is applicable to piping in gaseous and liquid hydrogen service and to pipelines in } \\
\text { gaseous hydrogen service. This code is applicable up to and including the joint connecting } \\
\text { the piping to associated pressure vessels and equipment, but not to the vessels and } \\
\text { equipment themselves. }\end{array}$ & ASME \\
\hline $\begin{array}{l}\text { CGA C-7 (2011) Guide to Preparation of Precautionary Labeling and Marking of Compressed } \\
\text { Gas Containers } \\
\text { Covers use of precautionary labels to warn of principal hazards. Includes general principles } \\
\text { and illustrative labels for several types of gases. }\end{array}$ & CGA \\
\hline $\begin{array}{l}\text { CGA G-5 (2011) Hydrogen Physical Properties } \\
\text { Includes the physical properties and how hydrogen is made, used, contained, and } \\
\text { transported. CGA G-5 complements G-5.4 and G-5.5 to ensure safe and effective hydrogen } \\
\text { installations. }\end{array}$ & CGA \\
\hline $\begin{array}{l}\text { CGA G-5.4 (2012) Standard for Hydrogen Piping Systems at Consumer Locations } \\
\text { Guides engineers, designers, and maintenance personnel through materials and components } \\
\text { selection to install a safe and effective hydrogen supply system at consumer sites. }\end{array}$ & CGA \\
\hline $\begin{array}{l}\text { CGA G-5.5 (2014) Hydrogen Vent Systems } \\
\text { Presents design guidelines for hydrogen vent systems for gaseous and liquid hydrogen } \\
\text { installations at consumer sites, and provides recommendations for their safe operation. }\end{array}$ & CGA \\
\hline
\end{tabular}


CGA S-1.1 (2011) Pressure Relief Device Standards-Part 1-Cylinders for Compressed Gases CGA

Specifies requirements for pressure relief devices on DOT cylinders for compressed gases.

Describes the various types of pressure relief devices, their limitations, design

considerations, maintenance, testing, and application for various gases.

CGA S-1.2 (2009) Pressure Relief Device Standards-Part 2-Portable Containers for

Compressed Gases

Specifies minimum recommended requirements for pressure relief devices for use on cargo tanks (tank trucks) and portable tanks (skid tanks) designed to DOT specifications.

Requirements are recommended for application to cargo and portable tanks that do not come within DOT or Transport Canada (TC) jurisdiction. Includes information on application, design, construction, testing, and maintenance of pressure relief devices.

CGA S-1.3 (2008) Pressure Relief Device Standards-Part 3-Stationary Storage Containers for Compressed Gases

States the minimum recommended requirements for pressure relief devices for storage containers constructed in accordance with the ASME or API/ASME codes. Includes information on application, design, construction, testing, and maintenance for pressure relief devices.

ANSI/CSA HGV2 (2014) Compressed hydrogen gas vehicle fuel containers

This standard contains requirements for the material, design, manufacture, marking, and testing of serially produced, refillable Type HGV2 containers intended only for the storage of compressed hydrogen gas for on-road vehicle operation. These containers:

a) are to be permanently attached to the vehicle;

b) have a capacity of up to 1,000 liters $\left(35.4 \mathrm{ft}^{3}\right)$ water capacity; and

c) have a nominal working pressure that does not exceed $70 \mathrm{MPa}$.

\section{DOT 49 CFR, Parts 171-180 Regulations for Transportation Equipment and the Transport of DOT} Hazardous Materials

Regulations related to transportation equipment and the transport of hydrogen are found in the various parts of Subtitle B, Chapter I, Subchapters A, B, and C in the various parts cited.

2015 International Building Code (IBC)

ICC

Establishes minimum requirements to safeguard public health, safety, and general welfare through structural strength, means of egress facilities, stability, sanitation, adequate light and ventilation, energy conservation, and safety to life and property from fire and other hazards attributed to the built environment.

2015 International Fire Code (IFC)

ICC

Establishes minimum requirements consistent with nationally recognized good practice for providing a reasonable level of safety and property protection from the hazards of fire, explosion, or dangerous conditions in new and existing buildings, structures, and premises.

2015 International Fuel Gas Code (IFGC)

ICC

Regulates the design, construction, installation, quality of materials, location, operation, and maintenance or use of fuel gas systems.

2015 International Mechanical Code (IMC)

ICC

Regulates the design, construction, installation, quality of materials, location, operation, and maintenance or use of mechanical systems. 


\begin{tabular}{|c|c|}
\hline Title of Code/Standard & Contact \\
\hline $\begin{array}{l}2015 \text { International Residential Code (IRC) } \\
\text { Provides minimum requirements for the construction, alteration, movement, replacement, } \\
\text { repair, and equipment of one- and two-family dwellings and townhouses not more than three } \\
\text { stories in height. }\end{array}$ & ICC \\
\hline $\begin{array}{l}2014 \text { National Electric Code (NFPA 70) } \\
\text { Provides requirements for the inspection, design, review, alteration, modification, } \\
\text { construction, maintenance, and testing of electrical systems and equipment, including } \\
\text { electrical installations at special events. }\end{array}$ & NFPA \\
\hline $\begin{array}{l}2016 \text { NFPA } 2 \text { Hydrogen Technologies Code } \\
\text { Applies to the design and installation of compressed natural gas (CNG) engine fuel systems } \\
\text { on vehicles of all types, including: a) original equipment manufacturers, b) vehicle converters, } \\
\text { and c) vehicle fueling (dispensing) systems. }\end{array}$ & NFPA \\
\hline $\begin{array}{l}2012 \text { NFPA 30A - Motor Fuel Dispensing Facilities and Repair Garages } \\
\text { Regulates the design, construction, maintenance, and testing of automotive and marine } \\
\text { service stations, service stations located inside buildings, and fleet vehicle service stations. }\end{array}$ & NFPA \\
\hline $\begin{array}{l}2013 \text { NFPA } 55 \text { - Compressed Gases and Cryogenic Fluids } \\
\text { Gaseous Hydrogen Systems } \\
\text { Covers the general principles recommended for the installation of gaseous hydrogen systems } \\
\text { on consumer premises where the hydrogen supply to the consumer premises originates } \\
\text { outside the consumer premises and is delivered by mobile equipment. } \\
\text { Liquefied Hydrogen Systems } \\
\text { Covers the general principles recommended for the installation of liquefied hydrogen systems } \\
\text { on consumer premises where the liquid hydrogen supply to the consumer premises } \\
\text { originates outside the consumer premises and is delivered by mobile equipment. }\end{array}$ & NFPA \\
\hline $\begin{array}{l}2015 \text { NFPA } 54 \text { - National Fuel Gas Code } \\
\text { Applies to the installation of fuel gas piping systems, fuel gas utilization equipment, and } \\
\text { related accessories. }\end{array}$ & NFPA \\
\hline $\begin{array}{l}2012 \text { NFPA } 5000 \text { - Building Construction and Safety Code } \\
\text { Applies to the construction, protection, and occupancy features necessary to minimize } \\
\text { danger to life and property. }\end{array}$ & NFPA \\
\hline $\begin{array}{l}2012 \text { NFPA } 1 \text { - Fire Code } \\
\text { Prescribes minimum requirements necessary to establish a reasonable level of fire and life } \\
\text { safety and property protection from the hazards created by fire, explosion, and dangerous } \\
\text { conditions. }\end{array}$ & NFPA \\
\hline \multicolumn{2}{|l|}{$\begin{array}{l}\text { ASME = ASME International, Two Park Avenue, New York, NY 10016, 800-843-2763 or 973-882-1170, } \\
\text { www.asme.org }\end{array}$} \\
\hline \multicolumn{2}{|l|}{$\begin{array}{l}\text { CGA = Compressed Gas Association, } 14501 \text { George Carter Way, \#103, Chantilly, VA 20151, 703-788-2700, } \\
\text { www.cganet.com }\end{array}$} \\
\hline \multicolumn{2}{|l|}{$\begin{array}{l}\text { ICC = International Code Council, } 500 \text { New Jersey Avenue, NW 6th Floor, Washington, DC 20001, } \\
\text { www.iccsafe.org }\end{array}$} \\
\hline $\begin{array}{l}\text { NFPA = National Fire Protection Association, } 1 \text { Batterymarch Park, Quincy, MA 02169, 800-344-3555, } \\
\text { www.nfpa.org } \\
\text { DOT = U.S. Department of Transportation, Research \& Special Programs Administration, Office of Haza } \\
\text { Materials Safety, East Building, 2nd Floor, } 1200 \text { New Jersey Ave., SE Washington, DC 20590, 800-467. } \\
\text { http://hazmat.dot.gov }\end{array}$ & \\
\hline
\end{tabular}


Table 2 provides a listing of the codes and standards that affect the design, installation, and operation of a hydrogen motor fuel dispensing facility for service to the public. This table is designed as a reference for enforcement personnel to determine the codes and/or standards that govern the design, testing, and certification of the fuel dispensing and storage equipment itself, as well as the codes and standards that cover the installation and siting of the facility and its fuel dispensing and storage equipment. The data in Table 2 also can be used by the design and engineering community to determine how to document compliance with the various codes and standards.

Table 2 is subdivided into five key sections that correspond to different aspects of a hydrogen motor fuel dispensing station:

1. Fuel Supply and Storage - Addresses either on-site storage in a storage vessel (e.g., hydrogen) or off-site storage and delivery of the fuel to the site via a piping system (e.g., natural gas) for on-site hydrogen generation.

○ 1.1 General

○ 1.2 Gaseous Hydrogen Storage

○ 1.3 Liquefied Hydrogen Storage.

2. General Station Siting - Addresses siting of the fuel dispensing station outdoors and indoors.

○ 2.1 General

○ 2.2 Outdoor Installations (not located within a building or structure; not enclosed by surrounding wall or roof construction; open to the outside environment)

○ 2.3 Indoor Installations (within a building or structure; enclosed by surrounding wall or roof construction; not open to the outside atmosphere).

3. Fueling Station Piping and Equipment - Provides codes and standards for the design of the piping and venting systems, compressors, pressure relief devices, shutoff valves, and dispensing and electrical systems (e.g., including those used for testing and listing the equipment).

○ 3.1 General

○ 3.2 Piping, Tubing, and Fittings

○ 3.3 Pressure Relief Devices (PRDs)

○ 3.4 Vent Systems

○ 3.5 Vaporizers

○ 3.6 Compressors and Dispensing Equipment.

4. Fire Protection - Addresses fire protection issues as they relate to the fuel dispensing station, including required safety precautions, fire protection systems, emergency shutdown equipment, and controls.

○ 4.1 Type of Construction 


\section{○ 4.2 Fire Protection Systems}

- 4.3 Additional Safety Precautions, Emergency Shutdown Equipment, and Controls.

5. Operating and Maintenance - Addresses operational permitting, training for staff, dispensing operations, tank filling and vehicular movement on-site, equipment maintenance, fire extinguishers, and signage.
○ 5.1 General
○ 5.2 Dispensing Requirements
○ 5.3 Operational Requirements.

Enforcement personnel can use the information in Table 2 during preliminary review of a hydrogen motor fuel dispensing facility to verify that each of the applicable provisions has been met. The number designated within Table 2 represents a major section heading within a code/standard or group of related codes/standards that covers a topic (e.g., Section 5.1, General). Please be aware that further subsections may be associated with each major section (e.g., Section 5.1.1) and further review by the user will be necessary. The following information is included in Table 2:

- Issue - A generic description of the provision or specific title used in the code/standard is provided.

- Requirement Description - A brief description of each of the primary code provisions is provided to give the user an overview of the code text.

- What to Look For - Guidance is provided to enforcement personnel on what to review for a hydrogen motor fuel dispensing facility submittal. The description includes the documentation that should be submitted (e.g., a label or listing) and where the information should be included in the plans or specifications.

- Code/Standard - The requisite code or standard that affects the design, installation, equipment specification, or operation of the hydrogen motor fuel dispensing facility is listed in abbreviated form.

As technology evolves, so do codes and standards. This guide was written based on information available at a specific point in time (2015-2016 timeframe), so readers should be aware that codes and standards covered herein may have been revised and/or a new version of this document created. It is highly recommended that the user verify that the latest editions of this document and, more importantly, the relevant codes and standards are being used. In terms of systems design, it is suggested that manufacturers become involved in the codes and standards development process and, to the degree possible, remain aware not only of currently published documents but also of ongoing revisions and new documents under development. 
Table 2. Codes and Standards for Hydrogen Motor Fuel Dispensing Facilities

\begin{tabular}{|c|c|c|c|}
\hline Issue & Requirement Description & What to Look For & Code/Standard \\
\hline \multicolumn{4}{|c|}{ 1.0 Fuel Supply and Storage } \\
\hline \multicolumn{4}{|l|}{ 1.1 General } \\
\hline $\begin{array}{l}\text { Identification and labeling of } \\
\text { storage containers }\end{array}$ & $\begin{array}{l}\text { Portable gaseous hydrogen containers } \\
\text { and manifold gaseous hydrogen supply } \\
\text { units shall be marked with the name } \\
\text { "HYDROGEN" or a legend such as "This } \\
\text { unit contains hydrogen" in accordance } \\
\text { with CGA. } \\
\text { Stationary liquefied hydrogen containers } \\
\text { shall be marked as follows: LIQUEFIED } \\
\text { HYDROGEN-FLAMMABLE GAS and in } \\
\text { accordance with ASME BPVC. }\end{array}$ & $\begin{array}{l}\text { Confirm marking of portable } \\
\text { containers. For stationary, verify } \\
\text { permanent nameplate information as } \\
\text { follows: manufacturing specification } \\
\text { and maximum allowable working } \\
\text { pressure. The nameplate is intended } \\
\text { to avoid any confusion about the } \\
\text { operating pressures and materials } \\
\text { being stored. }\end{array}$ & $\begin{array}{l}\text { ASME BPVC } \\
\text { CGA C-7 }-\S 6.2 .3, \S 6.6 .3 \\
\text { CGA G-5 }-\S 4.1, \S 4.2 .5 \\
\text { IFC - §5303.4, §5303.4.1- } \\
3, \S 5807.1 .5 \\
\text { NFPA } 2-\S 7.1 .4 .1 .7 \\
\S 7.1 .6, \S 8.1 .6 .1 .1 .1\end{array}$ \\
\hline Charging of cylinders & $\begin{array}{l}\text { Provides limitations such that cylinders } \\
\text { are not charged in excess of the design } \\
\text { pressure at the normal temperature. } \\
\text { Protection from temperature extremes is } \\
\text { also described. }\end{array}$ & $\begin{array}{l}\text { DOT, Transport Canada (TC), and } \\
\text { CSA GV2 shall be charged as } \\
\text { applicable. Other rules apply. }\end{array}$ & $\begin{array}{l}\text { CGA G-5 - §6 } \\
\text { CSA HGV2 } \\
\text { IFC - } \$ 5303.7 .4 \\
\S 5303.7 .6, \S 5303.7 .7 \\
\S 5803.1 .2\end{array}$ \\
\hline Material-specific regulations & $\begin{array}{l}\text { Indoor and outdoor use of flammable } \\
\text { gases and cryogenic fluids shall comply } \\
\text { with the appropriate material-specific } \\
\text { provisions of the applicable fire code. }\end{array}$ & $\begin{array}{l}\text { Consult and review material-specific } \\
\text { provisions. }\end{array}$ & $\begin{array}{l}\text { CGA G-5 - §2 } \\
\text { IFC }-\S 5305.9, \S 58, \\
\S 5804.1 \\
\text { IFGC }-\S 705, \S 705.3\end{array}$ \\
\hline Structural support & $\begin{array}{l}\text { Permanently installed containers must be } \\
\text { provided with substantial supports, } \\
\text { constructed of noncombustible material } \\
\text { securely anchored to firm foundations of } \\
\text { noncombustible material. } \\
\text { Compressed gas containers, cylinders, } \\
\text { tanks, and systems shall be secured } \\
\text { against accidental dislodgement. }\end{array}$ & $\begin{array}{l}\text { Confirm supports are of } \\
\text { noncombustible material. NFPA } \\
\text { protects liquid container supports } \\
\text { exceeding } 18 \text { inches ( } 46 \text { centimeters) } \\
\text { in height with a } 2 \text {-hour fire resistance } \\
\text { rating. }\end{array}$ & $\begin{array}{l}\text { IFC }-\S 5303.5 \\
\text { NFPA } 2-\S 7.3 \cdot 2 \cdot 1.4 .2\end{array}$ \\
\hline
\end{tabular}




\begin{tabular}{|c|c|c|c|}
\hline Issue & Requirement Description & What to Look For & Code/Standard \\
\hline $\begin{array}{l}\text { Distances from outdoor storage } \\
\text { areas to exposures }\end{array}$ & $\begin{array}{l}\text { Covers minimum separation distances (in } \\
\text { feet) between storage equipment and } \\
\text { features and a series of specified outdoor } \\
\text { exposures. Other rules apply (see } \\
\text { Sections } 2.1 \text { and } 2.2 \text { ). }\end{array}$ & $\begin{array}{l}\text { Consult the separation distance charts } \\
\text { as applicable. During plan review and } \\
\text { field inspection, confirm the separation } \\
\text { distances from various exposures. }\end{array}$ & NFPA 2 \\
\hline Shutoff valves & $\begin{array}{l}\text { A shutoff valve is required for containers } \\
\text { and piping to equipment. }\end{array}$ & $\begin{array}{l}\text { Verify the presence and operability of } \\
\text { this shutoff device. }\end{array}$ & $\begin{array}{l}\text { IFC }-\S 2309.5 .2 \\
\text { IFGC }-\S 704.1 .2 .5 \\
\text { CGA G-5.4 } \$ 4\end{array}$ \\
\hline Electrical equipment and wiring & $\begin{array}{l}\text { Fixed electrical equipment and wiring } \\
\text { shall be installed in accordance with the } \\
\text { applicable electrical code. Classified } \\
\text { areas are defined in the applicable table. }\end{array}$ & $\begin{array}{l}\text { Verify that electrical equipment, } \\
\text { connections, and wiring compliance } \\
\text { assessment are in accordance with } \\
\text { NFPA } 70 . \\
\text { Classified areas may be reduced or } \\
\text { eliminated as approved and by } \\
\text { positive pressure ventilation in } \\
\text { accordance with NFPA. }\end{array}$ & $\begin{array}{l}\text { NFPA } 2-\S 7.3 .2 .2 .2 .4 \\
\text { NFPA } 70-\S 501 \\
\text { NFPA 496: Standard for } \\
\text { Purged and Pressurized } \\
\text { Enclosures for Electrical } \\
\text { Equipment }\end{array}$ \\
\hline Protection from impact & $\begin{array}{l}\text { Guard posts or other approved means } \\
\text { shall be provided to protect storage tanks } \\
\text { and connected piping, valves, and } \\
\text { fittings; dispensing areas; and use areas } \\
\text { subject to vehicular damage. Container } \\
\text { valves shall be protected from physical } \\
\text { damage. }\end{array}$ & $\begin{array}{l}\text { Confirm the presence and suitability of } \\
\text { protection. The design of vehicle } \\
\text { barrier systems shall be in accordance } \\
\text { with the building code (as applicable). } \\
\text { Confirm the presence of protective } \\
\text { caps, collars, or similar devices for } \\
\text { containers. }\end{array}$ & $\begin{array}{l}\text { IFC }-\S 5003.9 .3 \\
\S 2309.5 .1, \S 5303.5 \\
\S 5303.6, \S 5806.4 .4 \\
\S 5803.1 .2 \\
\text { IFGC }-\S 707.1\end{array}$ \\
\hline $\begin{array}{l}\text { Security and access by } \\
\text { authorized personnel }\end{array}$ & $\begin{array}{l}\text { Areas used for the storage, use, and } \\
\text { handling of compressed gas containers, } \\
\text { cylinders, tanks, and systems shall be } \\
\text { secured against unauthorized entry and } \\
\text { safeguarded in an approved manner. }\end{array}$ & \begin{tabular}{|l|} 
Evaluate access to equipment, valves, \\
devices, etc., for maintenance. \\
Safeguards shall protect operational \\
controls and mechanisms from \\
unauthorized operation. Inspect the \\
storage site such that it is fenced and \\
posted to prevent entrance by \\
unauthorized personnel.
\end{tabular} & $\begin{array}{l}\text { IFC }-\S 5003.9 .2, \S 5303.5, \\
\S 5806.4 .4 \\
\text { IFGC }-\S 707.1\end{array}$ \\
\hline
\end{tabular}




\begin{tabular}{|c|c|c|c|}
\hline Issue & Requirement Description & What to Look For & Code/Standard \\
\hline Containers & $\begin{array}{l}\text { Hydrogen storage containers shall be } \\
\text { designed, constructed, and tested in } \\
\text { accordance with applicable requirements } \\
\text { of the ASME Boiler and Pressure Vessel } \\
\text { Code and federal DOT regulations. }\end{array}$ & $\begin{array}{l}\text { Hydrogen must be stored in } \\
\text { containers allowed for service with } \\
\text { hydrogen. The ASME container } \\
\text { should have a nameplate and DOT } \\
\text { cylinders should be stamped. }\end{array}$ & $\begin{array}{l}\text { ASME BPVC - §VIII } \\
\text { CGA G-5 - §4.1, §5, §7 } \\
\text { DOT } 49 \text { CFR } 171-190 \\
\text { IFC }-\S 5003.2, \S 5803.1 .2 \\
\text { NFPA } 2-\S 7.3 .2 .4 .1\end{array}$ \\
\hline $\begin{array}{l}\text { Cargo tanks (tank trucks) and } \\
\text { portable tanks (skid tanks) } \\
\text { designed to DOT specifications }\end{array}$ & $\begin{array}{l}\text { Each mobile hydrogen supply unit used } \\
\text { as part of a hydrogen system must be } \\
\text { secured to prevent movement. }\end{array}$ & $\begin{array}{l}\text { Inspect for wheel blocks and potential } \\
\text { equipment shifting. }\end{array}$ & NFPA $2-\S 8.3 .4 .5 .3$ \\
\hline \multicolumn{4}{|l|}{ 1.2 Gaseous Hydrogen Storage } \\
\hline $\begin{array}{l}\text { Separation from hazardous } \\
\text { conditions }\end{array}$ & $\begin{array}{l}\text { Aboveground storage of flammable and } \\
\text { combustible liquids or liquefied oxygen } \\
\text { shall be located on ground higher than } \\
\text { the hydrogen storage, except where } \\
\text { diking, diversion curbs, grading, or a } \\
\text { separating solid wall is provided to } \\
\text { prevent liquids accumulation within } 50 \\
\text { feet (15.2 meters) of the hydrogen } \\
\text { container. Other hazardous conditions } \\
\text { that pose exposure hazards also are } \\
\text { addressed. }\end{array}$ & $\begin{array}{l}\text { Separations from combustible waste, } \\
\text { ledges and platforms, falling objects, } \\
\text { and exposure to artificially created } \\
\text { temperature extremes shall be } \\
\text { evaluated during site inspection. }\end{array}$ & $\begin{array}{l}\text { IFC }-\S 5003.9 .8, \S 3003.5, \\
\S 5303.7, \S 5803.1 .2\end{array}$ \\
\hline Pressure relief devices (PRD) & $\begin{array}{l}\text { Covers PRD requirements related to } \\
\text { accessibility for maintenance, general } \\
\text { sizing, installation, and device integrity. }\end{array}$ & $\begin{array}{l}\text { See Section } 3.3 \text { for specific PRD } \\
\text { requirements. }\end{array}$ & $\begin{array}{l}\text { CGA G-5.4- } \$ 4.3 .1 \\
\text { IFC }-\S 58 \\
\text { IFGC }-\S 703.3 \\
\text { NFPA } 2-\S 10.3 .1 .4\end{array}$ \\
\hline
\end{tabular}




\begin{tabular}{|c|c|c|c|}
\hline Issue & Requirement Description & What to Look For & Code/Standard \\
\hline Bonding and grounding & $\begin{array}{l}\text { Stationary containers and mobile } \\
\text { hydrogen supply units shall be electrically } \\
\text { bonded to the facility before discharging } \\
\text { hydrogen. } \\
\text { Reference NFPA } 70-\S 250.90 \text { for } \\
\text { general bonding, } \S 250.100 \text { for bonding in } \\
\text { hazardous locations, and } \$ 250.104 \text { (B) } \\
\text { for bonding of "other metal piping." } \\
\text { See also Section } 3.1 \text {. }\end{array}$ & Bonding to eliminate ignition sources. & $\begin{array}{l}\text { CGA G5.4 - §6.5 } \\
\text { IFC - §5003.9.5 } \\
\text { IFGC }-\S 703.6, \S 704.4 \\
\text { NFPA 2- } \$ 7.3 .1 .2 .6, \\
\S 8.1 .9 .3 \\
\text { NFPA 70 - } 250.90, \\
\S 250.100, \S 250.104 \text { (B) } \\
\text { API RP 2003: Protection } \\
\text { Against Ignitions Arising } \\
\text { Out of Static, Lightning, } \\
\text { and Stray Currents }\end{array}$ \\
\hline \multicolumn{4}{|l|}{ 1.3 Liquefied Hydrogen Storage } \\
\hline Notices and placards & $\begin{array}{l}\text { Sites shall be placarded as follows: } \\
\text { "HYDROGEN-FLAMMABLE GAS NO } \\
\text { SMOKING-NO OPEN FLAMES". } \\
\text { All buildings, rooms, and areas } \\
\text { containing flammable gases are to be } \\
\text { properly marked. }\end{array}$ & $\begin{array}{l}\text { Signs must be in English as the } \\
\text { primary language and made of a } \\
\text { durable material with the size, color, } \\
\text { and lettering approved. }\end{array}$ & $\begin{array}{l}\text { IFC }-\S 5003.5 \\
\text { NFPA } 2-\S 7.1 .6 .5 .2 \\
\S 8.3 .2 .1 .3\end{array}$ \\
\hline Containers & $\begin{array}{l}\text { Hydrogen storage containers shall be } \\
\text { designed, constructed, and tested in } \\
\text { accordance with applicable requirements } \\
\text { of the ASME Boiler and Pressure Vessel } \\
\text { Code and federal DOT regulations. }\end{array}$ & $\begin{array}{l}\text { Hydrogen must be stored in } \\
\text { containers allowed for service with } \\
\text { hydrogen. The ASME container } \\
\text { should have a nameplate, and DOT } \\
\text { cylinders should be stamped. }\end{array}$ & $\begin{array}{l}\text { ASME BPVC - §VIII } \\
\text { CGA G5.4 - §4.1, §8 } \\
\text { DOT } 49 \text { CFR 171-190 } \\
\text { IFC - §5003.2, §5503.2 } \\
\text { NFPA } 2-\S 8.1 .2 .\end{array}$ \\
\hline $\begin{array}{l}\text { Cargo tanks (tank trucks) and } \\
\text { portable tanks (skid tanks) } \\
\text { designed to DOT specifications }\end{array}$ & $\begin{array}{l}\text { Each mobile hydrogen supply unit used } \\
\text { as part of a hydrogen system must be } \\
\text { secured to prevent movement. }\end{array}$ & $\begin{array}{l}\text { Inspect for potential equipment } \\
\text { shifting. }\end{array}$ & $\begin{array}{l}\text { NFPA } 2-\S 8.1 .7 .3 .1 \\
\text { IFC }-\S 5503.1 .1\end{array}$ \\
\hline
\end{tabular}




\begin{tabular}{|c|c|c|c|}
\hline Issue & Requirement Description & What to Look For & Code/Standard \\
\hline $\begin{array}{l}\text { Adjacent flammable and } \\
\text { combustible liquids or liquefied } \\
\text { oxygen storage }\end{array}$ & $\begin{array}{l}\text { Where hydrogen storage is located level } \\
\text { with or below such hazardous materials, } \\
\text { diking, diversion curbs, grading, or a } \\
\text { separating solid wall is required to } \\
\text { prevent liquids accumulation within } 50 \\
\text { feet ( } 15.2 \text { meters) of the hydrogen } \\
\text { container. }\end{array}$ & $\begin{array}{l}\text { Where present, confirm the means } \\
\text { and proximity of the measures to } \\
\text { protect adjacent hydrogen storage. }\end{array}$ & IFC - §5003.9.8, §5503.2 \\
\hline Shutoff valves & $\begin{array}{l}\text { A remotely controlled shutoff valve for } \\
\text { liquid withdrawal lines serving containers } \\
>2,000 \text { gallons }(7,570 \text { liters) is required. }\end{array}$ & $\begin{array}{l}\text { Confirm conspicuous installation and } \\
\text { operability. There shall be no } \\
\text { connections, flanges, or other } \\
\text { appurtenances allowed in the piping } \\
\text { between the shutoff valve and its } \\
\text { connection to the inner container. }\end{array}$ & $\begin{array}{l}\text { IFC }-\S 5503.2 .6 \\
\text { NFPA } 2-\S 8.1 .14 .1\end{array}$ \\
\hline Pressure relief devices (PRD) & $\begin{array}{l}\text { Covers PRD requirements related to } \\
\text { accessibility for maintenance, general } \\
\text { sizing, installation, and device integrity. }\end{array}$ & $\begin{array}{l}\text { See Section } 3.3 \text { for specific PRD } \\
\text { requirements. }\end{array}$ & $\begin{array}{l}\text { CGA G-5.4 - §4.3.1 } \\
\text { IFC }-\S 5503.2 \\
\text { NFPA } 2-\S 8.1 .4 .5\end{array}$ \\
\hline Bonding and grounding & $\begin{array}{l}\text { Liquefied hydrogen containers and } \\
\text { associated piping shall be electrically } \\
\text { bonded and grounded. }\end{array}$ & $\begin{array}{l}\text { Liquefied hydrogen containers and } \\
\text { associated piping must be properly } \\
\text { bonded and grounded in order to } \\
\text { prevent static discharges. It is critical } \\
\text { that the piping be bonded so that it will } \\
\text { discharge to ground. Bonding piping } \\
\text { to something that is not grounded will } \\
\text { not transfer the charge to ground. }\end{array}$ & $\begin{array}{l}\text { CGA G5.4 - §6.5 } \\
\text { IFC - } 5003.5 \\
\text { IFGC - } \$ 703.6, ~ \S 704.4 \\
\text { NFPA } 2-\S 8.1 .16 .2 \\
\text { API RP 2003: Protection } \\
\text { Against Ignitions Arising } \\
\text { Out of Static, Lightning, } \\
\text { and Stray Currents }\end{array}$ \\
\hline Notices and placards & $\begin{array}{l}\text { Sites shall be placarded as follows: } \\
\text { "LIQUEFIED HYDROGEN FLAMMABLE } \\
\text { GAS NO SMOKING-NO OPEN } \\
\text { FLAMES". } \\
\text { All buildings, rooms, and areas } \\
\text { containing cryogenic fluids are to be } \\
\text { properly marked. }\end{array}$ & $\begin{array}{l}\text { Signs must be in English as the } \\
\text { primary language and made of a } \\
\text { durable material with the size, color, } \\
\text { and lettering approved. }\end{array}$ & $\begin{array}{l}\text { IFC }-\S 5003.5, \S 5503.4 .1 \\
\text { NFPA } 2-\S 8.3 .2 .1 .3\end{array}$ \\
\hline
\end{tabular}




\begin{tabular}{|c|c|c|c|}
\hline Issue & Requirement Description & What to Look For & Code/Standard \\
\hline \multicolumn{4}{|c|}{ 2.0 General Station Siting } \\
\hline \multicolumn{4}{|l|}{ 2.1 General } \\
\hline Installation & $\begin{array}{l}\text { The building official is authorized to } \\
\text { require construction documents to be } \\
\text { prepared by a registered design } \\
\text { professional. Personnel familiar with } \\
\text { proper installation practices, construction, } \\
\text { and use of such systems shall supervise } \\
\text { installation of liquefied hydrogen } \\
\text { systems. }\end{array}$ & $\begin{array}{l}\text { At the time of permit application and at } \\
\text { various intervals during the project, } \\
\text { detailed technical information shall be } \\
\text { submitted to the building official in } \\
\text { accordance with state professional } \\
\text { registration laws. } \\
\text { No one person has the technical } \\
\text { knowledge to evaluate all of the } \\
\text { various operations, technologies, } \\
\text { processes, products, materials, and } \\
\text { uses from a safety standpoint. This } \\
\text { section also provides the code official } \\
\text { the authority to require the owner to } \\
\text { provide a technical opinion safety } \\
\text { report. It is critical that the preparer } \\
\text { have the proper background and } \\
\text { experience for the project because the } \\
\text { credibility of the report depends on } \\
\text { these qualifications. }\end{array}$ & $\begin{array}{l}\text { CGA G-5 - §7.1, §8 } \\
\text { CGA G-5.5- } \$ 6.1 \\
\text { IBC }-\S 106 \\
\text { IFC }-\S 104.7, \S 105.6 .41 \\
\S 5305.1, \S 5505.1 .1 \\
\text { IFGC }-\S 701 \\
\text { NFPA } 5000-\S 1.7 .6\end{array}$ \\
\hline $\begin{array}{l}\text { Adjacent flammable or } \\
\text { combustible liquids }\end{array}$ & $\begin{array}{l}\text { Covers circumstances in which the } \\
\text { fueling station is within a minimum- } \\
\text { specified distance (e.g., } 50 \text { feet or } 15 \\
\text { meters) of above-ground storage of all } \\
\text { classes of flammable and combustible } \\
\text { liquids. }\end{array}$ & $\begin{array}{l}\text { Assess the proximity of adjacent } \\
\text { flammable or combustible liquids. } \\
\text { Dikes, diversion curbs, grading, or } \\
\text { separating solid walls may be used to } \\
\text { prevent accumulation of these liquids } \\
\text { under the station. }\end{array}$ & NFPA $2-\S 7.3 .2 .3$ \\
\hline
\end{tabular}




\begin{tabular}{|c|c|c|c|}
\hline Issue & Requirement Description & What to Look For & Code/Standard \\
\hline $\begin{array}{l}\text { Separation distances from } \\
\text { equipment, features or } \\
\text { exposures }\end{array}$ & $\begin{array}{l}\text { Covers minimum separation distances (in } \\
\text { feet) between fueling station equipment } \\
\text { and features and a series of specified } \\
\text { outdoor exposures. Separations between } \\
\text { unloading connections for delivery } \\
\text { equipment and exposures, and between } \\
\text { container fill connections and parked } \\
\text { vehicles, are specified. Other rules apply } \\
\text { (see Section 2.2). }\end{array}$ & $\begin{array}{l}\text { Consult the separation distance charts } \\
\text { as applicable. During plan review and } \\
\text { field inspection confirm that the } \\
\text { separation distances from various } \\
\text { exposures, including unloading } \\
\text { connections and container fill } \\
\text { connections, are present. Appropriate } \\
\text { separation reduces the opportunity for } \\
\text { harmful impacts to the system and } \\
\text { decreases the severity of a hydrogen } \\
\text { release to life and property. }\end{array}$ & $\begin{array}{l}\text { IBC }-\S 302.1 .1, T 302.1 .1 \\
\text { IFC }-\S 2309.3 .1 .1 \\
\text { T2309.3.1.1, Liq: } \\
\text { §504.3.1.1.6.1, } \\
\text { T35504.3.1.1 } \\
\text { NFPA } 2-\S 7.3 .2 .3 \\
\text { NFPA } 2-\S 8.3 .2 .3 .1 .6\end{array}$ \\
\hline Location & $\begin{array}{l}\text { Refueling station systems and equipment } \\
\text { shall not be located beneath or where } \\
\text { exposed to failure to any of the following: } \\
\text { (a) electric power lines; (b) piping } \\
\text { containing all classes of flammable or } \\
\text { combustible liquids; (c) piping containing } \\
\text { other flammable gases; or (d) piping } \\
\text { containing oxidizing materials. }\end{array}$ & $\begin{array}{l}\text { Confirm and evaluate proximity of } \\
\text { refueling station systems and } \\
\text { equipment with respect to these } \\
\text { features. }\end{array}$ & $\begin{array}{l}\text { NFPA } 2-\S 7.3 .2 .3 \\
\text { NFPA } 2-\S 8.3 .2 .3 .1 .6\end{array}$ \\
\hline
\end{tabular}




\begin{tabular}{|c|c|c|c|}
\hline Issue & Requirement Description & What to Look For & Code/Standard \\
\hline Electrical equipment & $\begin{array}{l}\text { Any electrical equipment that is part of } \\
\text { the facility shall be offset (in feet) as } \\
\text { specified in Article } 501 \text { of NFPA } 70, \\
\text { National Electrical Code, for Class I, } \\
\text { Division } 2 \text { locations. } \\
\text { Electrical equipment within } 15 \text { feet ( } 4.6 \\
\text { meters) of gaseous hydrogen systems } \\
\text { shall comply. Electrical equipment within } \\
3 \text { feet (1 meter) of points of connection to } \\
\text { liquefied hydrogen systems is Division } 1 ; \\
\text { beyond } 3 \text { to } 25 \text { feet of the connection is } \\
\text { Division } 2 \text {. (Other exceptions apply.) }\end{array}$ & $\begin{array}{l}\text { The proximity of ignition sources with } \\
\text { respect to the electrical equipment } \\
\text { shall be identified, so located, and } \\
\text { addressed. }\end{array}$ & $\begin{array}{l}\text { ICC EC } \\
\text { IFC - §5503.6, §2309.2.3 } \\
\text { NFPA 2 - §7.3.2.2.2.4, } \\
\S 7.3 .2 .2 .3 .5, \S 7.3 .2 .3 .1 .2 \\
\text { NFPA 2 - §8.3.1.2.6, } \\
\text { NFPA 70 - §501.4, Wiring; } \\
\text { §01.5, Seals \& Drainage; } \\
\text { §01.6, Switches, Circuit } \\
\text { Breakers, Motor } \\
\text { Controllers, Fuses; §501.8 } \\
\text { Motors; §501.9, } \\
\text { Luminaries; §501.12 } \\
\text { Receptacles; §501.13 } \\
\text { Conductor Insulation; } \\
\text { §501.14 Signal and } \\
\text { Communication; §501.16 } \\
\text { Grounding }\end{array}$ \\
\hline $\begin{array}{l}\text { Separation distances from } \\
\text { equipment, features, or } \\
\text { exposures }\end{array}$ & $\begin{array}{l}\text { Hydrogen systems shall be located either } \\
\text { outdoors, in a separate building, or in a } \\
\text { "hydrogen cut-off room" (ICC) or a } \\
\text { "special room" (NFPA). Rules, locations } \\
\text { (in order of preference), and tables } \\
\text { specifying minimum separation distances } \\
\text { to specified exposures based on storage } \\
\text { capacity apply and shall be consulted. }\end{array}$ & $\begin{array}{l}\text { Consult the separation distance charts } \\
\text { as applicable. During plan review and } \\
\text { field inspection confirm that the } \\
\text { separation distances from various } \\
\text { exposures are present. Appropriate } \\
\text { separation reduces the opportunity for } \\
\text { harmful impacts to the system and } \\
\text { decreases the severity of a hydrogen } \\
\text { release to life and property. }\end{array}$ & $\begin{array}{l}\text { IBC }-\S 302.1 .1, \text { T302.1.1 } \\
\text { IFC - } 2309.3 .1 .1 \\
\text { T2309.3.1.1 } \\
\text { NFPA } 2-\S 7.3 .2 .1 .1 \\
\text { NFPA } 2-\S 8.3 .2 .2 .1 .4\end{array}$ \\
\hline
\end{tabular}




\begin{tabular}{|c|c|c|c|}
\hline Issue & Requirement Description & What to Look For & Code/Standard \\
\hline \multicolumn{4}{|l|}{ 2.2 Outdoor Installations } \\
\hline Weather protection & $\begin{array}{l}\text { Where walls, roofs, weather shelters, or } \\
\text { canopies are provided, they shall be } \\
\text { constructed of noncombustible materials. } \\
\text { NFPA permits the use of limited- } \\
\text { combustible materials. (Other rules } \\
\text { apply). } \\
\text { Hazardous material storage or use can } \\
\text { be considered outdoor storage or use } \\
\text { where all of the following are met: } \\
\text { 1. Structure supports do not obstruct } \\
\text { more than } 25 \% \text { of the perimeter of the } \\
\text { use area. } \\
\text { 2. The structure is located with respect to } \\
\text { buildings, lot lines, public ways, or means } \\
\text { of egress as required for the hazardous } \\
\text { material. } \\
3 . \text { The overhead structure is } \\
\text { noncombustible construction and limited } \\
\text { to } 1,500 \text { square feet }\left(140 \mathrm{~m}^{2}\right) \text {. }\end{array}$ & $\begin{array}{l}\text { Confirm construction type. Protective } \\
\text { barriers can be installed to provide a } \\
\text { greater measure of fire protection. } \\
\text { The } 1,500 \mathrm{ft}^{2} \text { may be exceeded if } \\
\text { either excess frontage or an automatic } \\
\text { sprinkler system is provided. }\end{array}$ & $\begin{array}{l}\text { CGA G-5 - §5, §8.2 } \\
\text { IBC }-\S 414.6 \\
\text { IFC - } 2309.3 .2, \S 5004.13 \\
\text { NFPA } 2-\S 6.6 .1 .2 \\
\text { NFPA } 2-\S 8.3 .2 .3 .1 .6\end{array}$ \\
\hline Gas detection system (optional) & $\begin{array}{l}\text { CGA offers an approved flammable gas } \\
\text { detection system as optional equipment. }\end{array}$ & $\begin{array}{l}\text { Review locations where detection is } \\
\text { specified. Locations shall be the most } \\
\text { likely to accumulate hydrogen or } \\
\text { develop a flammable atmosphere in } \\
\text { the event of a leak. } \\
\text { Confirm or field test detectors such } \\
\text { that they are set to alarm at } 1 \% \\
\text { hydrogen ( } 25 \% \text { LFL) and to shut down } \\
\text { at } 2 \% \text { hydrogen concentration. }\end{array}$ & $\begin{array}{l}\text { CGA G-5.4 - §4.3.6 } \\
\text { References as applicable: } \\
\text { IFC - } 2311.7 \\
\text { IFGC }-\S 706.3 .2 \\
\text { IMC - } \$ 502.16 \\
\text { NFPA } 2-\S 7.2 .2 .2 .2 .1 \\
\S 6.12 .2\end{array}$ \\
\hline
\end{tabular}




\begin{tabular}{|c|c|c|c|}
\hline Issue & Requirement Description & What to Look For & Code/Standard \\
\hline Roadway and yard surfaces & $\begin{array}{l}\text { Identifies where surfaces are to be } \\
\text { constructed of noncombustible materials. }\end{array}$ & $\begin{array}{l}\text { Confirm material and surface } \\
\text { conditions are present for sites } \\
\text { incorporating liquefied hydrogen } \\
\text { storage. Liquid air can drip from the } \\
\text { transfer piping of the delivery vehicle } \\
\text { and could contribute to a hazardous } \\
\text { condition. }\end{array}$ & $\begin{array}{l}\text { CGA G-5 - §8.2 } \\
\text { NFPA } 2-\S 8.3 .2 .3 .1 .5\end{array}$ \\
\hline \multicolumn{4}{|l|}{2.3 Indoor Installations } \\
\hline Ventilation and exhaust & $\begin{array}{l}\text { Establishes requirements for providing } \\
\text { ventilation exhaust and makeup air in } \\
\text { repair garages servicing lighter-than-air } \\
\text { fueled vehicles. The requirements are } \\
\text { relevant and applicable to indoor } \\
\text { installations of gaseous hydrogen } \\
\text { systems. } \\
\text { Establishes natural ventilation provisions } \\
\text { for certain indoor locations intended for } \\
\text { hydrogen generating or refueling } \\
\text { operations. Relevant to residential } \\
\text { applications where no more than three } \\
\text { motor vehicles are stored or serviced. } \\
\text { Requires ventilation to prevent the } \\
\text { accumulation of gaseous hydrogen in } \\
\text { cabinets or housings containing } \\
\text { hydrogen control or operating equipment. }\end{array}$ & $\begin{array}{l}\text { Review ventilation rates and details of } \\
\text { interconnection and operation. }\end{array}$ & $\begin{array}{l}\text { IFC }-\S 2311.7 \\
\text { IFGC }-\S 703.1 .2, \S 706.3 .2 \\
\text { IMC }-\S 502.16 \\
\text { NFPA } 2-\S 6.17 \\
\text { IFGC }-\S 703\end{array}$ \\
\hline
\end{tabular}




\begin{tabular}{|c|c|c|c|}
\hline Issue & Requirement Description & What to Look For & Code/Standard \\
\hline Ventilation rate and operation & $\begin{array}{l}\text { Establishes minimum continuous and } \\
\text { uniform air movement of } 1 \text { cubic foot per } \\
\text { minute per } 12 \text { cubic feet [0.00138 } \mathrm{m}^{3} /\left(\mathrm{s}^{*}\right. \\
\left.\mathrm{m}^{3}\right) \text { ] of room volume as the baseline level } \\
\text { of performance. } \\
\text { Operational provisions for such } \\
\text { ventilation systems need to be } \\
\text { interlocked with a continuously } \\
\text { monitoring, flammable gas detection } \\
\text { system. }\end{array}$ & $\begin{array}{l}\text { Confirm supply inlets are uniformly } \\
\text { arranged in exterior walls near the } \\
\text { floor. Exhaust outlets shall be } \\
\text { uniformly arranged in exterior walls at } \\
\text { the high point of the space. } \\
\text { Additionally, NFPA requires inlet and } \\
\text { outlet openings to be } 1 \mathrm{ft}^{2} / 1,000 \mathrm{ft}^{3}(1 \\
\left.\mathrm{m}^{2} / 305 \mathrm{~m}^{3}\right) \text { of room volume. Verify } \\
\text { that the detection system is installed, } \\
\text { operational, and activates when the } \\
\text { level of flammable gas exceeds } 25 \% \\
\text { of the lower flammability limit. }\end{array}$ & $\begin{array}{l}\text { IFC }-\S 2311.7 \\
\text { IFGC }-\S 706.3 .2 \\
\text { IMC }-\S 502.16 \\
\text { NFPA } 2-\S 6.17 .1, \S 6.18 .2 \\
\text { NFPA } 2-\S 6.19\end{array}$ \\
\hline Gas detection system & $\begin{array}{l}\text { Requires indoor installations to be } \\
\text { provided with an approved flammable } \\
\text { gas detection system. } \\
\text { NOTE: Indoor rooms exclusively housing } \\
\text { a gaseous hydrogen system are } \\
\text { constructed to requirements for a } \\
\text { "Hydrogen cut-off room" in ICC or a } \\
\text { "Special room" in NFPA. (Other rules } \\
\text { apply.) }\end{array}$ & $\begin{array}{l}\text { The flammable gas detection system } \\
\text { shall be of an approved type. Confirm } \\
\text { or field test detectors such that they } \\
\text { are set to alarm at } 1 \% \text { hydrogen ( } 25 \% \\
\text { lower flammable limit [LFL]) and to } \\
\text { shut down at } 2 \% \text { hydrogen } \\
\text { concentration. }\end{array}$ & $\begin{array}{l}\text { CGA G-5.4- } \$ 4.3 .6 \\
\text { IFC }-\S 2311.7 \\
\text { IFGC }-\S 706.3 .2 \\
\text { IMC }-\S 502.16 \\
\text { NFPA } 2-\S 10.3 .3 .2 .2 .7\end{array}$ \\
\hline \multicolumn{4}{|c|}{ 3.0 Fueling Station Piping and Equipment } \\
\hline \multicolumn{4}{|l|}{ 3.1 General } \\
\hline Electrolyzers & $\begin{array}{l}\text { Covers siting, design, ventilation, sensor } \\
\text { use, and other issues associated with the } \\
\text { use of electrolyzers. }\end{array}$ & $\begin{array}{l}\text { Gives requirements for siting of } \\
\text { electrolyzers, system connections, fire } \\
\text { protection, piping design, and the use } \\
\text { of listed or approved equipment. }\end{array}$ & Chapter 13 of NFPA 2 \\
\hline Insulation & $\begin{array}{l}\text { Covers the design of piping systems and } \\
\text { equipment to minimize the exposure of } \\
\text { piping, surfaces, and supports operating } \\
\text { at cryogenic temperatures. }\end{array}$ & $\begin{array}{l}\text { Inspect insulation levels and potential } \\
\text { personnel exposure points. Insulation } \\
\text { shall be noncombustible, vapor-tight } \\
\text { and suitable for exposure to the } \\
\text { environment. }\end{array}$ & $\begin{array}{l}\text { CGA G-5.4 - §6.2.2, } \S 6.3 \\
\text { CGA G-5.5- } § 6.11\end{array}$ \\
\hline
\end{tabular}




\begin{tabular}{|c|c|c|c|}
\hline Issue & Requirement Description & What to Look For & Code/Standard \\
\hline Bonding and grounding & $\begin{array}{l}\text { Equipment, containers, and associated } \\
\text { piping shall be electrically bonded and } \\
\text { grounded. Floor and floor coverings must } \\
\text { comply with provisions in CGA. } \\
\text { Reference NFPA } 70-\S 250.90 \text { for } \\
\text { general bonding, } \$ 250.100 \text { for bonding in } \\
\text { hazardous locations and } \$ 250.104 \text { (B) } \\
\text { for bonding of "other metal piping." } \\
\text { Reference NFPA } 70-\S 250.116 \text { non- } \\
\text { electric equipment (including containers } \\
\text { and skid-mounted tanks), NFPA } 70- \\
\S 250.118 \text { for connection of any } \\
\text { supplementary grounding electrode, and } \\
\text { NFPA } 70-\S 250.122 \text { for grounding } \\
\text { conductor sizing. } \\
\text { Containers and systems: } \\
\text { 1. Shall not be located where they could } \\
\text { become part of an electrical circuit, and } \\
\text { 2. Shall not be used for electrical } \\
\text { grounding. }\end{array}$ & $\begin{array}{l}\text { Hydrogen equipment, containers, and } \\
\text { associated piping must be properly } \\
\text { bonded in order to prevent static } \\
\text { discharges. } \\
\text { Verify the size of wire-type grounding } \\
\text { conductors such that they penetrate } \\
\text { moist soil and are not smaller than } \\
\text { Table } 250.122 . \text { The particular } \\
\text { grounding system of choice (metal } \\
\text { underground water or gas pipe } \\
\text { systems, metal building frame, others) } \\
\text { shall be confirmed and evaluated. } \\
\text { Other rules apply. } \\
\text { All metallic parts (piping, structure } \\
\text { supports) within a classified hazardous } \\
\text { area shall be at ground potential. }\end{array}$ & $\begin{array}{l}\text { CGA G-5.4- }-\$ 6.5 \\
\text { CGA G-5.5 - §6.10 } \\
\text { NFPA } 2-\S 8.3 .1 .2 .7 \\
\text { NFPA } 70-\S 250.90, \\
\S 250.100, \S 250.104, \\
\S 250.116, \S 250.118, \\
\S 250.122 \\
\text { IFC }-\S 5303.8, \S 5503.6, \\
\S 5803.1 .2\end{array}$ \\
\hline $\begin{array}{l}\text { Protection of structures and } \\
\text { personnel }\end{array}$ & $\begin{array}{l}\text { Establishes the means for minimizing } \\
\text { exposure of personnel to piping } \\
\text { operating at low temperatures and to } \\
\text { prevent air or condensate from } \\
\text { contacting surfaces not suitable for } \\
\text { cryogenic temperatures. } \\
\text { Uninsulated piping and equipment } \\
\text { operating at liquefied hydrogen } \\
\text { temperatures and cold vent piping shall } \\
\text { not be installed above asphalt surfaces } \\
\text { or other combustible materials. } \\
\text { Containers shall be protected from } \\
\text { contact with soil or unimproved surfaces, } \\
\text { and the surface graded to prevent } \\
\text { accumulation of water. }\end{array}$ & $\begin{array}{l}\text { Inspect and confirm insulation on } \\
\text { equipment operating at cryogenic } \\
\text { temperatures. } \\
\text { Asphalt and bituminous paving are } \\
\text { considered combustible materials. } \\
\text { Other combustible materials, such } \\
\text { those used with expansion joints, shall } \\
\text { be covered with noncombustible } \\
\text { material. Evaluate surfaces } \\
\text { underneath container storage. }\end{array}$ & $\begin{array}{l}\text { CGA G-5.4 - §6.2.2 } \\
\text { NFPA } 2-\S 8.3 .1 .2 .3 .8 \\
\text { OSHA CFR 29, Part 1910 } \\
\text { CGA G-5.5 - §6.12 } \\
\text { IFC - §53003.13, } \\
\S 5504.3 .1 .2 .2\end{array}$ \\
\hline
\end{tabular}




\begin{tabular}{|c|c|c|c|}
\hline Issue & Requirement Description & What to Look For & Code/Standard \\
\hline Protection from impact & $\begin{array}{l}\text { Guard posts or other approved means } \\
\text { shall be provided to protect storage } \\
\text { tanks and connected piping, valves, and } \\
\text { fittings; dispensing areas; and use areas } \\
\text { subject to vehicular damage. }\end{array}$ & $\begin{array}{l}\text { Confirm the presence and suitability of } \\
\text { protection. The design of vehicle } \\
\text { barrier systems shall be in accordance } \\
\text { with the building code (as applicable). }\end{array}$ & $\begin{array}{l}\text { IFC }-\S 5003.9 .3, \S 5403.5, \\
\S 5503.5, \S 5803.1 .2 \\
\text { IFGC }-\S 707.1 \\
\text { NFPA } 2-\S 7.1 .7 .3 .3 \\
\text { NFPA } 2-\S 8.3 .2 .3 .1 .2 \\
\text { NFPA } 5000\end{array}$ \\
\hline $\begin{array}{l}\text { Security and access by } \\
\text { authorized personnel }\end{array}$ & $\begin{array}{l}\text { Areas used for the storage, use, and } \\
\text { handling of compressed gas containers, } \\
\text { cylinders, tanks, and systems shall be } \\
\text { secured against unauthorized entry and } \\
\text { safeguarded in an approved manner. } \\
\text { Containers, piping, valves, regulating } \\
\text { equipment, and other accessories must } \\
\text { be readily accessible and protected } \\
\text { against physical damage and against } \\
\text { tampering. }\end{array}$ & $\begin{array}{l}\text { Devices and equipment must be } \\
\text { accessed for maintenance. Areas such } \\
\text { as yards, loading platforms, and any } \\
\text { area where gas containers, cylinders, } \\
\text { and tanks are used, handled, or stored } \\
\text { are to be secured and safeguarded } \\
\text { against unauthorized access. }\end{array}$ & $\begin{array}{l}\text { CGA G-5.4- } 66 \\
\text { IFC }-\S 5003.9 .2, \S 5403.5, \\
\S 5303.5, \S 5803.1 .2, \\
\S 5803.4 \\
\text { IFGC }-\S 707.1 \\
\text { NFPA } 2-\S 7.1 .7 .2 \\
\text { NFPA } 2-\S 8.1 .7\end{array}$ \\
\hline \multicolumn{4}{|c|}{ 3.2 Piping, Tubing, and Fittings } \\
\hline Materials & $\begin{array}{l}\text { Materials shall be approved for hydrogen } \\
\text { service in accordance with ASME B31.3 } \\
\text { for the rated pressure, volume, and } \\
\text { temperature of the gas or liquid } \\
\text { transported. Gray, ductile, or malleable } \\
\text { cast-iron pipe, valves, and fittings shall } \\
\text { not be used. } \\
\text { CGA specifies austenitic ( } 300 \text { series) } \\
\text { stainless steels meeting ASME } \\
\text { requirements for liquid and gaseous } \\
\text { hydrogen service, and allows plastic } \\
\text { under controlled conditions. IFGC } \\
\text { specifies Type } 304,304 \mathrm{~L}, \text { or } 316 \\
\text { stainless steel piping and tubing listed or } \\
\text { approved for gaseous hydrogen service. }\end{array}$ & $\begin{array}{l}\text { Hydrogen piping systems can consist } \\
\text { of structural members, vacuum } \\
\text { jackets, valve bodies and valve seats, } \\
\text { electrical and thermal insulation, } \\
\text { gaskets, seals, lubricants, and } \\
\text { adhesives and will involve a multitude } \\
\text { of materials. Hydrogen embrittlement } \\
\text { involves many variables and can } \\
\text { cause significant deterioration in the } \\
\text { mechanical properties of certain } \\
\text { metals. Thoroughly review material } \\
\text { selection methods and bills of lading, } \\
\text { quality control procedures, and } \\
\text { material test reports employed during } \\
\text { manufacture such that the materials } \\
\text { are suitable for hydrogen service. }\end{array}$ & $\begin{array}{l}\text { ASME B31.3 } \\
\text { CGA G-5.4- }-\$ 4.2 \\
\text { CGA G-5.5- } 55.5 \\
\text { IFGC }-\S 704.1 .2, \S 708 \\
\text { IFC }-\S 5501 \\
\text { NFPA } 2-\S 7.1 .15 .1 \\
\text { NFPA } 2-\S 8.1 .3 .1 \\
\text { ASME B31.3 } \\
\text { CGA G-5.4- }-\$ 4.2 .1 .2 \\
\text { IFGC }-\S 704.1 .2, \S 708\end{array}$ \\
\hline
\end{tabular}




\begin{tabular}{|c|c|c|c|}
\hline Issue & Requirement Description & What to Look For & Code/Standard \\
\hline Joints & $\begin{array}{l}\text { Joints on piping and tubing shall be listed } \\
\text { for hydrogen service, including welded, } \\
\text { brazed flared, socket, slip, or } \\
\text { compression fittings. Soft solder joints are } \\
\text { not permitted. } \\
\text { Threaded or flanged connections shall not } \\
\text { be used in areas other than hydrogen cut- } \\
\text { off rooms or outdoors. }\end{array}$ & $\begin{array}{l}\text { Inspect several joining methods during } \\
\text { construction to verify that they are of } \\
\text { the approved type and suitable for } \\
\text { hydrogen service. Mechanical joints } \\
\text { must have electrical continuity or be } \\
\text { connected with a bonding strap. Any } \\
\text { gaskets or sealants shall be listed for } \\
\text { use with hydrogen. CGA indicates that } \\
\text { graphite is preferred. Specific sealant } \\
\text { gasketing and packing materials are } \\
\text { included in CGA G-5.4 and G-5.5. }\end{array}$ & $\begin{array}{l}\text { CGA G-5.4- } \$ 6.1 .2 \\
\S 6.1 .4, \S 6.2 .1 \\
\text { CGA G-5.5 - } 6.4-\S 6.10 \\
\text { IFGC }-\S 704.1 .2 .4 \\
\text { NFPA } 2-\S 7.3 .2 .4 .4 .1 \\
\text { NFPA } 2-\S 8.3 .1 .2 .2 .3\end{array}$ \\
\hline $\begin{array}{l}\text { Valve, gauge, regulator, and } \\
\text { piping component materials }\end{array}$ & $\begin{array}{l}\text { All valves, gauges, regulators, and other } \\
\text { piping components shall be listed or } \\
\text { approved for hydrogen service for the } \\
\text { rated pressure, volume, and temperature } \\
\text { of the gas or liquid transported. Cast-iron } \\
\text { valves and fittings shall not be used. } \\
\text { The manufacturer or the hydrogen } \\
\text { supplier shall recommend valves gauges, } \\
\text { regulators, and other accessories for } \\
\text { hydrogen service. }\end{array}$ & $\begin{array}{l}\text { Confirm that mechanical fittings and } \\
\text { special joints are used as required by } \\
\text { ASME. Valves, gauges, and regulators } \\
\text { used must be suitable for hydrogen } \\
\text { service. } \\
\text { CGA specifies use of safety glass and } \\
\text { blowout plugs on pressure gauges. } \\
\text { Also, valve and seat types (e.g., metal- } \\
\text { to-metal or metal-to-soft material) for } \\
\text { various isolation, emergency isolation, } \\
\text { and check valve types are discussed. } \\
\text { Other rules apply. }\end{array}$ & $\begin{array}{l}\text { CGA G-5.4 - §4.3.8, } \$ 4.3 .1 \\
\text { CGA G-5.5 } \\
\text { NFPA } 2-\S 10.3 .1 .1\end{array}$ \\
\hline $\begin{array}{l}\text { Piping in floors, concealed } \\
\text { locations, and underground }\end{array}$ & $\begin{array}{l}\text { Requirements for piping underground, in } \\
\text { solid floors, and outdoors, including soil } \\
\text { tests and welded construction (as } \\
\text { applicable) and prohibition of valves, } \\
\text { joints, and connections (for underground), } \\
\text { are described. }\end{array}$ & $\begin{array}{l}\text { Verify depth as required by fuel gas } \\
\text { code (as applicable). Evaluate piping } \\
\text { layout and need for protection from } \\
\text { frost and surface loads with the casing } \\
\text { ventilated to the outdoors. Review soil } \\
\text { test results to determine need for } \\
\text { cathodic protection. }\end{array}$ & $\begin{array}{l}\text { IFGC }-\S 704.1 .2 .3 .5 \\
\S 704.1 .2 .3 .6 \\
\text { CGA G-5.4- } \$ 6.3\end{array}$ \\
\hline Pressure regulators & $\begin{array}{l}\text { Establishes design, installation, and } \\
\text { protection for regulators. }\end{array}$ & $\begin{array}{l}\text { Confirm the location of regulators and } \\
\text { that their operation cannot be affected } \\
\text { by freezing rain, sleet, snow, ice, mud, } \\
\text { insects, or debris. }\end{array}$ & $\begin{array}{l}\text { CGA G-5.4 } \\
\text { CGA G-5.5, CGA E-4 } \\
\text { NFPA } 2-\S 10.3 .1 .6\end{array}$ \\
\hline
\end{tabular}




\begin{tabular}{|c|c|c|c|}
\hline Issue & Requirement Description & What to Look For & Code/Standard \\
\hline Pressure gauges & $\begin{array}{l}\text { Covers installation of gauges and the } \\
\text { pressure variables that require monitoring } \\
\text { to determine whether the system is } \\
\text { functional. }\end{array}$ & $\begin{array}{l}\text { Confirm the presence of and } \\
\text { functionality of the gauges. Gauges } \\
\text { shall report compression discharge } \\
\text { pressure, storage pressure, and fuel } \\
\text { supply container fill pressure. }\end{array}$ & $\begin{array}{l}\text { CGA G-5 - §6.3 } \\
\text { CGA G-5.5 } \\
\text { CGA E-4 } \\
\text { NFPA } 2-\S 10.3 .1 .6 .3 \\
\text { NFPA } 2-. \S 8.1 .6 .4\end{array}$ \\
\hline Shutoff valves & $\begin{array}{l}\text { Piping to equipment shall be provided } \\
\text { with an accessible, manual shutoff valve. } \\
\text { Valves shall not be installed between the } \\
\text { PRD and the container protected by the } \\
\text { PRD and shall be conspicuous and } \\
\text { readily accessible. (See also Sections } 1.3 \\
\text { and 3.5.) }\end{array}$ & $\begin{array}{l}\text { Inspect locations, accessibility, and } \\
\text { operability of shutoff valves. }\end{array}$ & $\begin{array}{l}\text { IFC }-\S 2309.5 .2, \S 5503.2 .6 \\
\text { IFGC }-\S 703.3 .1 \\
\S 704.1 .2 .5 .1 \\
\text { NFPA } 2-\S 8.1 .3 .1 .5\end{array}$ \\
\hline $\begin{array}{l}\text { Piping and hoses (general } \\
\text { design and support) }\end{array}$ & $\begin{array}{l}\text { Requirements for piping (including vent } \\
\text { piping) and hoses cover design, } \\
\text { protection, and support. Additional areas } \\
\text { where there are requirements include } \\
\text { hose electrical continuity and bonding, } \\
\text { manifold connections, pipe thread joining } \\
\text { materials, prohibited weakening of piping } \\
\text { and tubing resulting from bending, access } \\
\text { to joints, venting to safe points of } \\
\text { discharge, limitations on the use of hose } \\
\text { connections, and recycling of unused fuel. }\end{array}$ & $\begin{array}{l}\text { Inspect direct runs and manifolds for } \\
\text { support and provisions for expansion } \\
\text { and vibration control. Review piping } \\
\text { bending methods and inspect bends } \\
\text { for visible signs of weakness. (Third- } \\
\text { party inspection of assembly methods } \\
\text { may be necessary.) Thirty-six-inch } \\
\text { (910-millimeter) metallic hose lengths } \\
\text { are permitted for flexibility (readily } \\
\text { visible and protected from damage). } \\
\text { (See also Section 3.4.) }\end{array}$ & $\begin{array}{l}\text { CGA G-5.4- } \$ 4.3 .8, \S 6.1 \\
\text { CGA G-5.5- } \$ 6.1, \S 6.2 \\
\text { NFPA } 2-\S 7.1 .15 \\
\text { NFPA } 2-\S 8.1 .3 .1\end{array}$ \\
\hline
\end{tabular}




\begin{tabular}{|c|c|c|c|}
\hline Issue & Requirement Description & What to Look For & Code/Standard \\
\hline Testing & $\begin{array}{l}\text { After installation, all field-erected piping } \\
\text { tubing and hose and hose assemblies } \\
\text { shall be tested and proved hydrogen } \\
\text { gas-tight for the rated pressure, volume, } \\
\text { and temperature of the gas or liquid } \\
\text { transported in that portion of the system. }\end{array}$ & $\begin{array}{l}\text { A testing and purging procedure } \\
\text { should be prepared and reviewed. } \\
\text { While methods for testing hydrogen } \\
\text { piping vary, an approved method, such } \\
\text { as what is outlined in ASME B31.3, } \\
\text { often incorporate procedures that can } \\
\text { be characterized as follows: } \\
\text { 1. Perform a pressure test (CGA } \\
\text { indicates a mix of at least } 10 \% \text { helium } \\
\text { in inert gas is preferred) at } 1.5 \text { times } \\
\text { maximum working pressure, } 30 \\
\text { minutes per } 500 \text { cubic feet of pipe } \\
\text { volume. } \\
\text { 2. After the pressure test, check for } \\
\text { pressure decay. If some leakage is } \\
\text { detected, use soap/water to find the } \\
\text { local leaks (bubbles). } \\
\text { 3. Energize the piping with hydrogen } \\
\text { and check for local leaks with a "sonic } \\
\text { tester" or a "sniffer" (hand-held } \\
\text { combustibility tester). } \\
\text { lf the test "fails" the above procedure, } \\
\text { purge the system, fix the leak, and } \\
\text { repeat the process until it "passes." } \\
\text { Sometimes a "sonic test" is used as } \\
\text { part of yearly preventive maintenance. }\end{array}$ & $\begin{array}{l}\text { ASME B31.12 } \\
\text { CGA G-5.4- } \$ 7.2 \\
\text { CGA G-5.5- } \$ 6.13, \S 6.14 \\
\text { IFGC - } \$ 705, \S 705.3 \\
\text { NFPA } 2-\S 7.3 .2 .4 .4 \\
\text { NFPA } 2-\S 8.1 .3 .1 .9\end{array}$ \\
\hline Purging & Covers purging with inert gas. & $\begin{array}{l}\text { A testing and purging procedure } \\
\text { should be prepared and reviewed. } \\
\text { CGA refers to ASME B31.3 methods } \\
\text { and requires residual oxygen to be } \\
\text { reduced to less than } 1 \% \text {. }\end{array}$ & $\begin{array}{l}\text { ASME B31.3/12 } \\
\text { CGA G-5.4 - } 77.3 \\
\text { IFGC }-\S 705.3 \\
\text { NFPA } 2-\S 6.21 .1 .5 \\
\text { NFPA } 2-\S 10.3 .1 .10 \\
\text { NFPA } 2-\S 8.2 .3 .1 .10\end{array}$ \\
\hline
\end{tabular}




\begin{tabular}{|c|c|c|c|}
\hline Issue & Requirement Description & What to Look For & Code/Standard \\
\hline Cleaning & $\begin{array}{l}\text { Before placing into hydrogen service, } \\
\text { piping systems shall be cleaned. }\end{array}$ & $\begin{array}{l}\text { Review CGA for details of cleaning } \\
\text { procedures and visual and wipe tests } \\
\text { to be performed. }\end{array}$ & $\begin{array}{l}\text { CGA G-5.4 - §5 } \\
\text { CGA G-5.5 - §6.9 }\end{array}$ \\
\hline \multicolumn{4}{|c|}{ 3.3 Pressure Relief Devices (PRDs) } \\
\hline Where required & $\begin{array}{l}\text { Containers and portions of the system } \\
\text { subject to overpressure shall be protected } \\
\text { by pressure relief devices. }\end{array}$ & $\begin{array}{l}\text { Inspect containers, equipment, and } \\
\text { systems for location and operability of } \\
\text { PRDs. }\end{array}$ & $\begin{array}{l}\text { CGA G-5.4 - §4.3.1 } \\
\text { IFC - §5503.2, §5803.1.2 } \\
\text { NFPA } 2-\S 7.1 .5 .5 \\
\text { NFPA } 2-\S 8.1 .4\end{array}$ \\
\hline Sizing & $\begin{array}{l}\text { Gaseous hydrogen containers and } \\
\text { stationary and portable liquefied } \\
\text { hydrogen containers shall be equipped } \\
\text { with appropriately sized PRDs. } \\
\text { PRDs shall be designed and installed in } \\
\text { accordance with the appropriate CGA (S- } \\
1.1 \text { for cylinders, S-1.2 for cargo and } \\
\text { portable tanks, S-1.3 for storage } \\
\text { containers) or ASME BPVC utilizing } \\
\text { commodity-based requirements, as } \\
\text { applicable. Other rules apply. }\end{array}$ & $\begin{array}{l}\text { PRDs shall be installed in accordance } \\
\text { with the manufacturer's instructions } \\
\text { and designed to operate properly. } \\
\text { Review manufacturer's information to } \\
\text { support sizing to the specifications of } \\
\text { the container type such that the } \\
\text { maximum design pressure of the } \\
\text { container is not exceeded. }\end{array}$ & $\begin{array}{l}\text { CGA G-5 - §4.2.2, §8.2 } \\
\text { CGA G-5.4- } \$ 4.3 .1 \\
\text { CGA S-1.1 - §5, §5.4 } \\
\text { CGA S-1.2 } \$ 4.3 .2, \S 5 \\
\text { CGA S-1.3 }-\S 4.3 .3, \S 5 \\
\text { IFC }-\S 5503.2 .3 \\
\text { IFGC }-\S 703.3, \S 703.4 \\
\text { NFPA } 2-\S 7.1 .5 .5 \\
\text { NFPA } 2-\S 8.1 .4 \\
\text { DOT } 49 \text { CFR , Pts } 174-179\end{array}$ \\
\hline
\end{tabular}




\begin{tabular}{|c|c|c|c|}
\hline Issue & Requirements & What to Look For & Code/Standard \\
\hline Location of discharge & $\begin{array}{l}\text { Covers unobstructed discharge to the } \\
\text { outdoors, location and arrangement of } \\
\text { escaping liquid or gas to protect } \\
\text { containers, adjacent structures, and } \\
\text { personnel. For pressure vessels, PRDs } \\
\text { must be installed so they discharge in a } \\
\text { vertical position. }\end{array}$ & $\begin{array}{l}\text { Confirm arrangement of discharge and } \\
\text { location. }\end{array}$ & 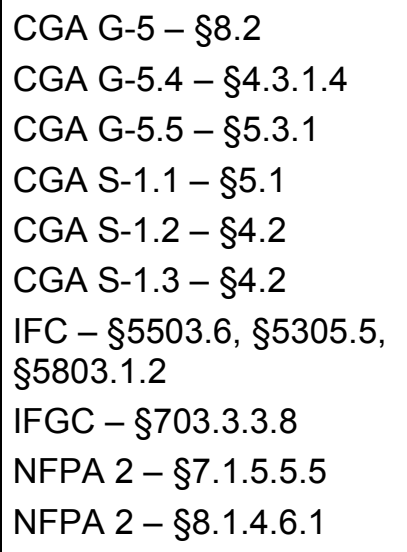 \\
\hline Obstructions & $\begin{array}{l}\text { Addresses protection and location of the } \\
\text { PRD so that moisture or other debris } \\
\text { cannot interfere with proper operation of } \\
\text { the device. }\end{array}$ & $\begin{array}{l}\text { Verify the installation and positioning } \\
\text { of PRDs. Ice formation on PRDs can } \\
\text { render them inoperable. }\end{array}$ & 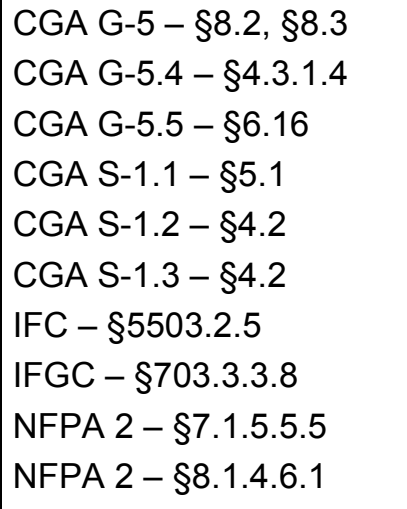 \\
\hline $\begin{array}{l}\text { Fueling transfer system } \\
\text { overpressure protection }\end{array}$ & $\begin{array}{l}\text { Covers installation of an overpressure } \\
\text { protection device (other than a rupture } \\
\text { disc device) in the fueling transfer } \\
\text { system. }\end{array}$ & $\begin{array}{l}\text { The PRD shall be set no higher than } \\
1.25 \text { times the service pressure of the } \\
\text { refueling nozzle. Consult the "marked } \\
\text { set pressure" requirements for the } \\
\text { PRD using the applicable CGA. }\end{array}$ & $\begin{array}{l}\text { CGA G-5 - §4.2.2, §8.3 } \\
\text { CGA S-1.1 - §4 } \\
\text { CGA S-1.2- } § 4.3, \S 4.3 .2 \\
\text { CGA S-1.3- } \$ 4.1 .2\end{array}$ \\
\hline
\end{tabular}




\begin{tabular}{|c|c|c|c|}
\hline Issue & Requirements & What to Look For & Code/Standard \\
\hline \multicolumn{4}{|l|}{ 3.4 Vent Systems } \\
\hline General design & $\begin{array}{l}\text { The vent structure must be designed to } \\
\text { withstand ice, wind, and seismic loadings } \\
\text { and located such that burning of the } \\
\text { discharged hydrogen can proceed safely. }\end{array}$ & $\begin{array}{l}\text { Evaluate structural support, height, } \\
\text { and separation distances for the } \\
\text { proposed vent outlet location. }\end{array}$ & $\begin{array}{l}\text { CGA G-5.5- §4.2, §4.3, } \\
\S 5.2, \S 5.3 \\
\text { IBC T2209.5.4.1, } \\
\S 2209.5 .4 .2 \\
\text { NFPA } 5000\end{array}$ \\
\hline Purging flow rate & $\begin{array}{l}\text { Specifies the maximum purging flow to } \\
\text { be equal to the PRD release rate in } \\
\text { accordance with CGA using non- } \\
\text { "engulfing fire" conditions or the } \\
\text { maximum on-site production rate, } \\
\text { whichever is larger. Also addresses } \\
\text { manifolded vent sources to a common } \\
\text { stack, miter cut exits, siting distances } \\
\text { from exposures, and thermal/radiation } \\
\text { impingement. }\end{array}$ & $\begin{array}{l}\text { The flow rating shall be clearly } \\
\text { specified (in cfm) at PRD rating } \\
\text { pressure for the code official. The } \\
\text { PRD rating pressure is the inlet static } \\
\text { pressure at which the relieving } \\
\text { capacity of the PRD is determined. } \\
\text { Reductions to PRD flow requirements } \\
\text { may be applied when the storage is } \\
\text { protected from an "engulfing fire." }\end{array}$ & $\begin{array}{l}\text { CGA G-5.4 - §4.3.1 } \\
\text { CGA G-5.5 - §5.2, } 55.3 \\
\text { CGA S-1.3 - §4.3.3, §5 }\end{array}$ \\
\hline Materials and joining methods & $\begin{array}{l}\text { Covers requirements for vent piping } \\
\text { materials and joining methods. } \\
\text { IFC specifies the associated PRD vent } \\
\text { pipe system shall be designed for the } \\
\text { maximum backpressure but not less than } \\
335 \text { psig }(2,310 \mathrm{kPa}) \text {. CGA indicates that } \\
\text { a system designed for } 150 \text { psig ( } 1,030 \\
\mathrm{kPa} \text { ) is sufficient. } \\
\text { (See Section } 3.2 \text { for specific material and } \\
\text { joining discussion.) }\end{array}$ & $\begin{array}{l}\text { Thoroughly review material selection } \\
\text { methods and bills of lading, quality } \\
\text { control procedures, and material test } \\
\text { reports employed during manufacture } \\
\text { such that the materials and joining } \\
\text { methods are suitable for hydrogen } \\
\text { service. }\end{array}$ & $\begin{array}{l}\text { ASME B31.3 } \\
\text { CGA G-5.4- } § 4.2, \S 4.3 .1 \\
\text { CGA G-5.5- } \$ 5.3 .4, \S 5.4 \text {, } \\
\S 5.5\end{array}$ \\
\hline
\end{tabular}




\begin{tabular}{|c|c|c|c|}
\hline Issue & Requirements & What to Look For & Code/Standard \\
\hline Obstructions & $\begin{array}{l}\text { Vent piping shall be designed or located } \\
\text { so that moisture or other debris cannot } \\
\text { freeze or collect in a manner that would } \\
\text { interfere with proper operation of the } \\
\text { device. }\end{array}$ & $\begin{array}{l}\text { Confirm that vent piping is present and } \\
\text { that the protection is suitable for the } \\
\text { intended protective function. }\end{array}$ & $\begin{array}{l}\text { CGA G-5 - §8.2, §8.3 } \\
\text { CGA G-5.4- } \$ 4.3 .1 .4 \\
\text { CGA G-5.5 - §6.16 } \\
\text { IFC - §5503.3 } \\
\text { NFPA } 2-\S 7.1 .5 .5 .5 \\
\text { NFPA } 2-\S 8.1 .5\end{array}$ \\
\hline Insulation & $\begin{array}{l}\text { Covers the design of uninsulated, cold } \\
\text { vent piping systems and equipment to } \\
\text { minimize the exposure of piping, } \\
\text { surfaces, and supports operating at } \\
\text { cryogenic temperatures. }\end{array}$ & $\begin{array}{l}\text { Inspect insulation levels and potential } \\
\text { personnel exposure points. Insulation } \\
\text { shall be noncombustible, vapor-tight, } \\
\text { and suitable for exposure to the } \\
\text { environment. }\end{array}$ & $\begin{array}{l}\text { CGA G-5.4 - §6.2.2, } \$ 6.3 \\
\text { CGA G-5.5 - §6.11 }\end{array}$ \\
\hline $\begin{array}{l}\text { Testing and cleaning (see } \\
\text { Section } 3.2 \text { for testing and } \\
\text { cleaning requirements) }\end{array}$ & $\begin{array}{l}\text { After installation, all field-erected vents } \\
\text { shall be tested and proved hydrogen gas- } \\
\text { tight for the rated pressure, volume, and } \\
\text { temperature of the gas transported. } \\
\text { Before placing into hydrogen service, } \\
\text { piping systems shall be cleaned. }\end{array}$ & $\begin{array}{l}\text { A testing and purging procedure } \\
\text { should be prepared and reviewed. } \\
\text { Review CGA for details of cleaning } \\
\text { procedures and visual and wipe tests } \\
\text { to be performed. }\end{array}$ & $\begin{array}{l}\text { ASME B31.3 } \\
\text { CGA G-5.4- } \$ 5, \S 7.2 \\
\text { CGA G-5.5- } \$ 6.13, \S 6.14 \\
\text { IFGC - } \$ 705, \S 705.3 \\
\text { NFPA } 2-\S 10.3 .1 .10\end{array}$ \\
\hline Signage & $\begin{array}{l}\text { Ice shall be prevented from forming on } \\
\text { PRDs and making them inoperable. }\end{array}$ & $\begin{array}{l}\text { Confirm the conspicuous placement of } \\
\text { signage on the container near the } \\
\text { pressure relief valve vent stack and on } \\
\text { the vent stack that warns against } \\
\text { spraying water on or in the vent } \\
\text { opening. }\end{array}$ & NFPA 2 - §8.3.1.2.2.4 \\
\hline
\end{tabular}




\begin{tabular}{|c|c|c|c|}
\hline Issue & Requirements & What to Look For & Code/Standard \\
\hline \multicolumn{4}{|l|}{ 3.5 Vaporizers } \\
\hline Vaporizers & $\begin{array}{l}\text { General requirements for liquefied hydrogen } \\
\text { vaporizers are summarized here: } \\
\text { 1. Must be supported on suitable } \\
\text { foundations. } \\
\text { 2. Must be anchored and accommodate the } \\
\text { effects of expansion and contraction. } \\
\text { 3. Must be protected on the hydrogen and } \\
\text { heating media sections with PRDs. } \\
\text { 4. Indirect heat (air, steam, water) shall be } \\
\text { used for vaporization. } \\
\text { 5. A low-temperature shutoff switch or valve } \\
\text { is required in the vaporize discharge piping. }\end{array}$ & $\begin{array}{l}\text { Confirm the presence of a suitable } \\
\text { foundation and accommodations for } \\
\text { expansion control. Verify the } \\
\text { presence of PRDs. Assess their } \\
\text { operability. Direct heating must be } \\
\text { avoided to prevent ignition of } \\
\text { hydrogen. Verify indirect source of } \\
\text { heat. To prevent flow of liquefied } \\
\text { hydrogen into system portions } \\
\text { designed for gaseous hydrogen in } \\
\text { the event of the loss of the heat } \\
\text { source, a shutoff switch or } \\
\text { automatic valve is required. Confirm } \\
\text { the presence of the equipment and } \\
\text { operability. }\end{array}$ & $\begin{array}{l}\text { IFC }-\S 5503.1 .3 \\
\S 5503.2 .2, \S 5503.5 \\
\text { IFGC }-\S 708 \\
\text { NFPA } 2-\S 8.3 .1 .2 .5\end{array}$ \\
\hline \multicolumn{4}{|c|}{ 3.6 Compressors and Dispensing Equipment } \\
\hline Fuel dispensing devices & $\begin{array}{l}\text { These sections provide requirements for } \\
\text { listing, location, and installation of fuel } \\
\text { dispensing devices (also known as vehicle } \\
\text { fueling appliances). Location and approval } \\
\text { of emergency disconnect switches are also } \\
\text { specified. }\end{array}$ & $\begin{array}{l}\text { Evaluate manufacturer's listing and } \\
\text { installation instructions for the } \\
\text { dispensing device. Confirm } \\
\text { installation in accordance with } \\
\text { manufacturer's instructions. Verify } \\
\text { location for dispensing devices. }\end{array}$ & $\begin{array}{l}\text { IFC }-\S 2303, \S 2309.2 .2 \\
\S 2309.3 .3 \\
\text { NFPA } 2-\S 10.3 .1 .1\end{array}$ \\
\hline $\begin{array}{l}\text { Temperature corrected fill } \\
\text { pressure flow shutoff }\end{array}$ & $\begin{array}{l}\text { A shutoff device required for stopping fuel } \\
\text { flow automatically when a fuel supply } \\
\text { container reaches the temperature- } \\
\text { corrected fill pressure. }\end{array}$ & $\begin{array}{l}\text { Verify the presence and operability } \\
\text { of this automatic shutoff device. The } \\
\text { device must be checked annually by } \\
\text { manually tripping the hold-open } \\
\text { linkage. }\end{array}$ & $\begin{array}{l}\text { IFC }-\S 2305.2 .2 \\
\text { NFPA } 2-\S 10.3 .1 .13 .3\end{array}$ \\
\hline
\end{tabular}




\begin{tabular}{|c|c|c|c|}
\hline Issue & Requirements & What to Look For & Code/Standard \\
\hline Hoses and hose connections & $\begin{array}{l}\text { Covers general requirements for hoses, } \\
\text { including materials and selection, testing, } \\
\text { protection and support, and limitations on } \\
\text { the use of hose connections. }\end{array}$ & $\begin{array}{l}\text { Hose and hose connections shall be } \\
\text { listed for hydrogen service. Use of } \\
\text { hoses shall be limited to vehicle } \\
\text { fueling, inlet connection to } \\
\text { compression equipment, and } 36- \\
\text { inch (910-millimeter) metallic } \\
\text { lengths in piping for flexibility } \\
\text { (readily visible and protected from }\end{array}$ & $\begin{array}{l}\text { IFC }-\S 2309.2 .2 \\
\text { NFPA } 2-\S 10.3 .1 .8\end{array}$ \\
\hline Breakaway devices & $\begin{array}{l}\text { Establishes provisions for breakaway } \\
\text { protection, their location, installation, } \\
\text { arrangement, and separation forces. }\end{array}$ & $\begin{array}{l}\text { Confirm listing and installation of } \\
\text { these devices in accordance with } \\
\text { the manufacturer's installation } \\
\text { instructions such that in the event of } \\
\text { a pull-away, hydrogen gas ceases } \\
\text { to flow at any separation. }\end{array}$ & $\begin{array}{l}\text { IFC - §2306.7.5, } \\
\S 2306.7 .6, \S 2309.2 .2 \\
\text { NFPA 2 - §10.3.3.3.4.3 (H) } \\
\text { SAE 2600: Compressed } \\
\text { Hydrogen Vehicle Fueling } \\
\text { Connection Devices }\end{array}$ \\
\hline Connector depressurization & $\begin{array}{l}\text { Transfer systems must be capable of } \\
\text { depressurizing to facilitate disconnection. } \\
\text { Bleed connections shall lead to a safe point } \\
\text { of discharge. }\end{array}$ & $\begin{array}{l}\text { Confirm the presence and means } \\
\text { for depressurization. Verify location } \\
\text { of the point of discharge. }\end{array}$ & $\begin{array}{l}\text { CGA G-5 - §8.3 } \\
\text { IFC }-\S 2309.2 .2 \\
\text { NFPA } 2-\S 7.3 .4 .2 .6\end{array}$ \\
\hline $\begin{array}{l}\text { Stray or impressed currents and } \\
\text { bonding }\end{array}$ & $\begin{array}{l}\text { Covers stray or impressed currents and } \\
\text { where static protection (bonding) is not } \\
\text { required. }\end{array}$ & $\begin{array}{l}\text { Inquire whether stray currents are } \\
\text { used or may be present. If yes, then } \\
\text { verify the presence and continuity of } \\
\text { protective measures (such as } \\
\text { cathode protection). As relates to } \\
\text { bonding required, inquire about the } \\
\text { unloading of fuel, the coupling type } \\
\text { (hose, tubing, or piping), and if both } \\
\text { halves of the coupling are metallic } \\
\text { and in direct contact. Other rules } \\
\text { apply. }\end{array}$ & $\begin{array}{l}\text { NFPA } 2-\S 10.3 .1 .16 \\
\text { CGA G-5.4 - } 6.5 \\
\text { IFC }-\S 2703.9 .5, \S 3406.7 \\
\text { IFGC }-\S 703.6, \S 704.4 \\
\text { NFPA } 70-\S 250.90, \\
\S 250.100, \S 250.104 \\
\text { API RP 2003: Protection } \\
\text { Against Ignitions Arising } \\
\text { Out of Static, Lightning, } \\
\text { and Stray Currents }\end{array}$ \\
\hline Shutoff valves & $\begin{array}{l}\text { Shutoff valves for piping served by an } \\
\text { outdoor compressor or storage system shall } \\
\text { be located outside the building. }\end{array}$ & $\begin{array}{l}\text { Inspect location, accessibility, } \\
\text { proximity, and operability of shutoff } \\
\text { valves. }\end{array}$ & NFPA $2-\S 10.3 .1 .17 .5$ \\
\hline
\end{tabular}




\begin{tabular}{|c|c|c|c|}
\hline Issue & Requirement Description & What to Look For & Code/Standard \\
\hline Compressor self-closing valve & $\begin{array}{l}\text { Specifies a self-closing valve at the inlet of } \\
\text { the compressor. }\end{array}$ & $\begin{array}{l}\text { Verify that the valve will shut off the } \\
\text { gas supply to the compressor when } \\
\text { an emergency shutdown device is } \\
\text { activated, or a power failure occurs, } \\
\text { or the power to the compressor is } \\
\text { switched to the off position. } \\
\text { Verify presence and functionality of } \\
\text { the valve(s). }\end{array}$ & NFPA 2 - $\$ 10.3 \cdot 3 \cdot 2.3 .7$ (B) \\
\hline \multicolumn{4}{|c|}{ 4.0 Fire Protection } \\
\hline \multicolumn{4}{|l|}{ 4.1 Type of Construction } \\
\hline $\begin{array}{l}\text { Rooms or spaces exclusively } \\
\text { housing a gaseous hydrogen } \\
\text { system }\end{array}$ & $\begin{array}{l}\text { Protective walls or roofs shall be } \\
\text { constructed of noncombustible materials. } \\
\text { ICC permits 1- or 2-hour interior walls } \\
\text { based on use group, interior openings with } \\
\text { self-closing devices, or a source capture } \\
\text { exhaust system and no operable windows. } \\
\text { NFPA permits noncombustible and limited- } \\
\text { combustible 2-hour interior walls (at least } \\
\text { one wall shall be to the exterior) and no } \\
\text { openings to other building areas. Explosion } \\
\text { control is required. }\end{array}$ & $\begin{array}{l}\text { These materials will provide greater } \\
\text { protection in the event of a fire. }\end{array}$ & $\begin{array}{l}\text { IBC }- \text { T302.1.1 } \\
\text { IFC }-\S 911, \S 5503.3 \\
\S 5804.1 .1 \\
\text { IFGC }-\S 706.3 \\
\text { NFPA } 2-\S 7.3 .3 .2 .3 \\
\text { NFPA } 2-\S 8.2 .2 .2 .2 \\
\text { NFPA } 2-\S 10.3 .3 .2 .2 .5\end{array}$ \\
\hline \multicolumn{4}{|l|}{ 4.2 Fire Protection Systems } \\
\hline $\begin{array}{l}\text { Weather protection and } \\
\text { canopies }>1,500 \mathrm{ft}^{2}\left(140 \mathrm{~m}^{2}\right)\end{array}$ & $\begin{array}{l}\text { The } 1,500-\mathrm{ft}^{2} \text { limitation for canopy area may } \\
\text { be exceeded if either excess frontage or an } \\
\text { automatic sprinkler system is provided. }\end{array}$ & $\begin{array}{l}\text { Where a canopy exceeds this } \\
\text { threshold, verify excess frontage or } \\
\text { presence of an automatic sprinkler } \\
\text { system. }\end{array}$ & $\begin{array}{l}\text { IBC }-\S 414.6 \\
\text { IFC }-\S 2309.3 .2, \S 5004.13 \\
\text { NFPA } 2-\S 6.6\end{array}$ \\
\hline
\end{tabular}




\begin{tabular}{|c|c|c|c|}
\hline Issue & Requirement Description & What to Look For & Code/Standard \\
\hline Portable fire extinguishers & $\begin{array}{l}\text { Covers general and specific requirements } \\
\text { for the selection, installation, and } \\
\text { maintenance of portable fire extinguishers. }\end{array}$ & $\begin{array}{l}\text { Confirm the presence, extinguisher } \\
\text { type, and location in accordance with } \\
\text { the building code and NFPA } 10 . \\
\text { NFPA specifies a rating not less than } \\
20-B: C \text {. ICC specifies two } 2-A: 20- \\
\text { B:C and } 75 \text { feet from pumps, } \\
\text { dispensers, and tank fill openings. }\end{array}$ & $\begin{array}{l}\text { IFC }-\S 906, \S 2305.5 \\
\text { NFPA } 2-\S 10.33 .3 .4 .3 \\
(E)\end{array}$ \\
\hline \multicolumn{4}{|c|}{ 4.3 Additional Safety Precautions, Emergency Shutdown Equipment, and Controls } \\
\hline Container valve & $\begin{array}{l}\text { Covers requirements for manually operated } \\
\text { container valves on DOT and Transport } \\
\text { Canada (TC) storage cylinders. A backflow } \\
\text { valve at the container fill line is required to } \\
\text { prevent flow back into the container. Other } \\
\text { safety measures include the proximity of the } \\
\text { shutoff valve in manifolded container groups } \\
\text { and precautions for the use of excess-flow } \\
\text { valves (EFVs). }\end{array}$ & $\begin{array}{l}\text { Review the presence, location, and } \\
\text { operability of these preventive } \\
\text { measures, means for shutoff, } \\
\text { shutdown, and backflow prevention. } \\
\text { For EFVs, verify that the closing flow } \\
\text { is less than the flow rating of the } \\
\text { piping system that would result from } \\
\text { a pipeline rupture downstream. }\end{array}$ & $\begin{array}{l}\text { CGA G-5.4- } \$ 4.3 .4 \\
\text { IFC }-\S 911, \S 5503.3 \\
\text { IFGC }-\S 706.3 \\
\text { NFPA } 2-\S 10.3 .1 .17\end{array}$ \\
\hline Compressed gas controls & $\begin{array}{l}\text { Controls shall be designed to prevent } \\
\text { materials from entering or leaving process } \\
\text { systems. Automatic controls shall be fail- } \\
\text { safe. }\end{array}$ & $\begin{array}{l}\text { Review the presence, location, and } \\
\text { operability of these controls to } \\
\text { prevent material entry or release. } \\
\text { Verify control circuit operation, reset } \\
\text { capabilities, and procedures to } \\
\text { confirm that a safe condition is } \\
\text { restored. }\end{array}$ & IFC - §5305.2, §5803.1.3 \\
\hline
\end{tabular}




\begin{tabular}{|c|c|c|c|}
\hline Issue & Requirement Description & What to Look For & Code/Standard \\
\hline $\begin{array}{l}\text { Emergency manual shutdown } \\
\text { devices }\end{array}$ & $\begin{array}{l}\text { Covers location and operation of } \\
\text { emergency manual shutdown devices and } \\
\text { control circuits. Such devices shall be } \\
\text { conspicuous and distinctly marked. }\end{array}$ & $\begin{array}{l}\text { Review the presence, location, and } \\
\text { operability of these preventive } \\
\text { measures and means for shutdown. } \\
\text { Emergency manual shutdown } \\
\text { devices shall be located in } \\
\text { dispensing, generation, and } \\
\text { compression areas. These devices, } \\
\text { when activated, must shut off the } \\
\text { power supply and gas supply to all } \\
\text { storage, dispensing, generation, and } \\
\text { compression equipment. Verify } \\
\text { control circuit operation, reset } \\
\text { capabilities, and procedures to } \\
\text { confirm that a safe condition is } \\
\text { restored. }\end{array}$ & $\begin{array}{l}\text { CGA G-5.4- } \$ 4.3 .3 \\
\text { IFC }-\S 5305.2, \S 3205.3 .2 \\
\S 3503.1 .3 \\
\text { NFPA } 2-\S 10.3 .1 .17 .7 .1\end{array}$ \\
\hline Fast-fill stations & $\begin{array}{l}\text { Specifies locations for "quarter turn" manual } \\
\text { shutoffs and shutoff conditions for lines } \\
\text { between storage and dispenser(s). }\end{array}$ & $\begin{array}{l}\text { Review the location of manual } \\
\text { shutoffs between the storage system } \\
\text { and the dispensing system. }\end{array}$ & $\begin{array}{l}\text { NFPA } 2-\S 10.3 \cdot 3 \cdot 2 \cdot 3.7 \\
\text { (B) }\end{array}$ \\
\hline \multicolumn{4}{|c|}{5.0 Operating and Maintenance } \\
\hline \multicolumn{4}{|l|}{ 5.1 General } \\
\hline Vehicle access & $\begin{array}{l}\text { Storage containers shall be accessible to } \\
\text { mobile supply equipment at ground level and } \\
\text { to authorized personnel. }\end{array}$ & $\begin{array}{l}\text { A site access survey could be } \\
\text { utilized to evaluate turning radii, } \\
\text { approach, and site circulation for the } \\
\text { anticipated delivery vehicles. }\end{array}$ & $\begin{array}{l}\text { IFC }-\S 5505.4 .2 \\
\text { NFPA } 2-\S 7.3 .4 .2 .1 \\
\text { NFPA } 2-\S 8.3 .4 .5\end{array}$ \\
\hline
\end{tabular}




\begin{tabular}{|c|c|c|c|}
\hline Issue & Requirement Description & What to Look For & Code/Standard \\
\hline Ignition source control & $\begin{array}{l}\text { Ignition sources shall be identified and kept } \\
\text { out of the fueling area. Storage and refueling } \\
\text { areas must be kept clean and free of } \\
\text { combustibles. }\end{array}$ & $\begin{array}{l}\text { Identify and resolve ignition } \\
\text { sources. }\end{array}$ & $\begin{array}{l}\text { CGA G-5 - §8.4 } \\
\text { IFC - §2205.4, §2205.7, } \\
\S 3503.1 .4 \\
\text { IFGC - §707.1, §706.3.4 } \\
\text { NFPA } 2-\S 7.1 .26 \\
\S 7.1 .9 .1 .6, \S 4.12 .3 \\
\text { NFPA } 2-\S 8.3 .2 .2 .2 .3 \\
\S 8.3 .4 .5 .13 \\
\text { NFPA } 2-\S 10.3 .1 .13 .9\end{array}$ \\
\hline Warning signs & $\begin{array}{l}\text { A warning sign with the words "STOP } \\
\text { MOTOR, NO SMOKING, FLAMMABLE } \\
\text { GAS" shall be posted at the dispensing } \\
\text { station and in compressor areas. }\end{array}$ & $\begin{array}{l}\text { Confirm such signage is } \\
\text { conspicuous, within sight of the } \\
\text { dispenser, and warns against (1) } \\
\text { filling of unapproved containers, (2) } \\
\text { smoking, and (3) running the engine } \\
\text { during the refueling process. }\end{array}$ & $\begin{array}{l}\text { IFC }-\S 2205.6 \\
\text { IFGC }-\S 706.3 .7 \\
\text { NFPA } 2-\S 10.3 .3 .2 .2 .15\end{array}$ \\
\hline Maintenance & $\begin{array}{l}\text { Address the requirements for maintaining } \\
\text { system components and safety equipment at } \\
\text { dispensing operations. Repairs shall be by } \\
\text { persons qualified to perform work on this } \\
\text { equipment. }\end{array}$ & $\begin{array}{l}\text { Equipment must be both properly } \\
\text { installed and properly maintained. } \\
\text { Conduct annual inspections as } \\
\text { required. }\end{array}$ & $\begin{array}{l}\text { CGA G-5.4 - §8 } \\
\text { IFC }-\S 107, \S 2205.2 \\
\text { IFGC }-\S 707.1 \\
\text { NFPA } 2-\S 7.1 .28 \\
\text { NFPA } 2-\S 8.1 .2 \\
\text { NFPA } 2-\S 10.3 .1 .11 .6 \\
\S 10.3 .1 .11 .7, \S 10.3 .1 .11 .3 \\
\end{array}$ \\
\hline $\begin{array}{l}\text { Fire prevention and emergency } \\
\text { planning }\end{array}$ & $\begin{array}{l}\text { Requires a written fire prevention and } \\
\text { emergency plan based on the size and } \\
\text { location of the refueling station. }\end{array}$ & $\begin{array}{l}\text { Reporting of emergencies, } \\
\text { coordination with emergency } \\
\text { response personnel, and } \\
\text { emergency plans and procedures } \\
\text { for managing or responding to } \\
\text { emergencies shall comply with } \\
\text { these provisions. }\end{array}$ & $\begin{array}{l}\text { IFC }-\S 107, \S 404, \S 407, \\
\S 2703.9 \\
\text { NFPA } 5000\end{array}$ \\
\hline
\end{tabular}




\begin{tabular}{|c|c|c|c|}
\hline Issue & Requirement Description & What to Look For & Code/Standard \\
\hline \multicolumn{4}{|l|}{ 5.2 Dispensing Requirements } \\
\hline Fuel dispensing & $\begin{array}{l}\text { Requirements for posting operating } \\
\text { instructions and what information to post } \\
\text { about the refueling process (e.g., turn off } \\
\text { the vehicle, set the brake) are included. }\end{array}$ & $\begin{array}{l}\text { Clearly understandable operating } \\
\text { instructions for the use of the } \\
\text { dispenser must be posted on the } \\
\text { dispenser. The location shall be } \\
\text { approved by the fire code official. }\end{array}$ & $\begin{array}{l}\text { IFC }-\S 2204.3 .4 \\
\text { NFPA } 2-\S 10.3\end{array}$ \\
\hline \multicolumn{4}{|l|}{ 5.3 Operational Requirements } \\
\hline Required operational permits & $\begin{array}{l}\text { General conditions requiring operational } \\
\text { permits and collection of information } \\
\text { demonstrating continued compliance with } \\
\text { the unique requirements for particular } \\
\text { operations. } \\
\text { CGA requires that a permanent record of } \\
\text { inspections and repairs shall be maintained. }\end{array}$ & $\begin{array}{l}\text { This data collection and recording } \\
\text { activity should be carried out by both } \\
\text { the facility operator and the authority } \\
\text { having jurisdiction. }\end{array}$ & $\begin{array}{l}\text { CGA G-5.4 - §8 } \\
\text { CGA G-5.5- } § 7 \\
\text { IBC } \\
\text { IFC - §105.6, §105.6.9, } \\
\S 105.6 .11, \S 105.6 .17 \\
\S 105.6 .40 \\
\text { NFPA } 5000\end{array}$ \\
\hline Operator training & $\begin{array}{l}\text { Covers required training for station } \\
\text { employees and operating personnel who } \\
\text { use and maintain the station. }\end{array}$ & $\begin{array}{l}\text { Confirm the presence of and review } \\
\text { the employee and operator training } \\
\text { program. }\end{array}$ & $\begin{array}{l}\text { IFC }-\S 2209.4, \S 406 \\
\text { NFPA } 5000\end{array}$ \\
\hline $\begin{array}{l}\text { Safely transporting hydrogen } \\
\text { (liquid or gaseous) from the } \\
\text { production plant to the fueling } \\
\text { station }\end{array}$ & $\begin{array}{l}\text { The fueling station shall be designed so } \\
\text { that it is accessible to delivery equipment. } \\
\text { There should be provisions for emergency } \\
\text { equipment access (e.g., fire department } \\
\text { equipment). }\end{array}$ & $\begin{array}{l}\text { If there are restrictions on the access } \\
\text { roads leading to the site with respect } \\
\text { to transporting hydrogen (e.g., } \\
\text { tunnels), the amelioration } \\
\text { requirements should be specified. }\end{array}$ & $\begin{array}{l}\text { Applicable local zoning } \\
\text { code or ordinance relating } \\
\text { to siting of fueling stations } \\
\text { IBC }-\S 506.2 \\
\text { NFPA } 2-\S 7.3 .4 .2\end{array}$ \\
\hline $\begin{array}{l}\text { Regular inspections (system } \\
\text { components, containers, and } \\
\text { grounding) }\end{array}$ & $\begin{array}{l}\text { Regular inspections of storage containers, } \\
\text { system components, and grounding } \\
\text { systems are specified. }\end{array}$ & $\begin{array}{l}\text { Attend or verify the pressure testing } \\
\text { of containers if out of service in } \\
\text { excess of one year. The system and } \\
\text { components (e.g., pressure relief } \\
\text { devices) shall be checked to } \\
\text { determine if they are operable and } \\
\text { properly set. }\end{array}$ & $\begin{array}{l}\text { CGA G-5.4- } \$ 8 \\
\text { CGA G-5.5- } 88 \\
\text { NFPA } 2-\S 8.2 .3 .1 .1 .3 \\
\S 7.1 .28 .2\end{array}$ \\
\hline
\end{tabular}




\begin{tabular}{|c|c|c|c|}
\hline Issue & Requirement Description & What to Look For & Code/Standard \\
\hline Regular inspections (hoses) & $\begin{array}{l}\text { Covers re-inspection and leak tests } \\
\text { required of hoses. }\end{array}$ & $\begin{array}{l}\text { After the station is constructed, } \\
\text { vehicle fueling hoses shall be } \\
\text { examined visually at such intervals } \\
\text { as are necessary to ensure that they } \\
\text { are safe for use. Manufacturer's } \\
\text { instructions are to be consulted for } \\
\text { leak test requirements. }\end{array}$ & $\begin{array}{l}\text { IFC }-\S 2205.4, \S 2205.7 \\
\text { NFPA } 2-\S 10.3 .3 .3 .4 .3 \\
(J)\end{array}$ \\
\hline $\begin{array}{l}\text { Regular inspections (pressure } \\
\text { relief devices [PRDs]) }\end{array}$ & $\begin{array}{l}\text { Stationary containers and portable tanks } \\
\text { shall be tested every five years. Cylinders } \\
\text { shall be examined at each refilling. When } \\
\text { filling containers, PRDs shall be periodically } \\
\text { examined externally for corrosion, damage, } \\
\text { plugging of external channels, mechanical } \\
\text { defects, and leakage. }\end{array}$ & $\begin{array}{l}\text { Revisit for testing during operational } \\
\text { permitting as called for. More } \\
\text { frequent examinations may be } \\
\text { warranted, depending on service } \\
\text { condition or manufacturer's } \\
\text { recommendations. }\end{array}$ & $\begin{array}{l}\text { CGA S-1.1- } \S 8 \\
\text { CGA S-1.2- } 88.6 \\
\text { CGA S-1.3- } \$ 8.6\end{array}$ \\
\hline $\begin{array}{l}\text { Regular inspections (pressure } \\
\text { relief valves [PRVs]) }\end{array}$ & $\begin{array}{l}\text { PRVs shall be tested every five years. } \\
\text { When filling containers, PRVs shall be } \\
\text { periodically examined externally for } \\
\text { corrosion, damage, plugging of external } \\
\text { channels, mechanical defects, and leakage. }\end{array}$ & $\begin{array}{l}\text { Revisit for testing during operational } \\
\text { permitting as called for. More } \\
\text { frequent examinations may be } \\
\text { warranted, depending on service } \\
\text { condition or manufacturer's } \\
\text { recommendations. }\end{array}$ & $\begin{array}{l}\text { NFPA } 2-\S 10.3 .11 .1 \\
\text { IFC }-\S 3203.2\end{array}$ \\
\hline $\begin{array}{l}\text { Maintenance and visual } \\
\text { inspection (hydrogen vent } \\
\text { systems) }\end{array}$ & $\begin{array}{l}\text { Provides for visual and physical inspections } \\
\text { as well as manual venting operations and } \\
\text { field repairs. }\end{array}$ & $\begin{array}{l}\text { Revisit for testing during operational } \\
\text { permitting annually. Visual } \\
\text { inspections include looking for } \\
\text { operational obstructions (nests, } \\
\text { vegetation), inspecting the support } \\
\text { systems, brackets, wires, etc. } \\
\text { Physically inspect the water drain } \\
\text { device at the bottom of the stack. } \\
\text { Qualified technicians shall check } \\
\text { operation of vent system valves. }\end{array}$ & CGA G-5.5 - §7, §8 \\
\hline
\end{tabular}




\section{Case Study}

\subsection{Project Description Case Study Location}

The project described in this case study is located at the National Renewable Energy Laboratory (NREL) in Golden, Colorado. The objective of the project was to build a 700 bar (10,000 psi) hydrogen fueling station that would be used to conduct research on station safety and reliability and to support a fleet of fuel cell electric vehicles that would also be used for research purposes. The station also could eventually, although not initially, be used as a public fueling station.

The project began in 2013 and was completed successfully in March 2015.

\subsection{Installation Type}

The hydrogen fueling station for the NREL Energy Systems Integration Facility was designed by engineers in NREL's hydrogen and fuel cell systems engineering group with input from engineers at Air Products and Chemicals, Inc. The station uses a combination of low-pressure (less than 420 bar) hydrogen storage and high-pressure ( 875 bar) hydrogen storage to achieve complete fueling of vehicles that require 700 bar. The crossover from low- to high-pressure fueling is accomplished though the gas panel shown in Figure 2. Note that the dual tower dispenser shown in Figure 2 can dispense low-pressure (350 bar) hydrogen. 


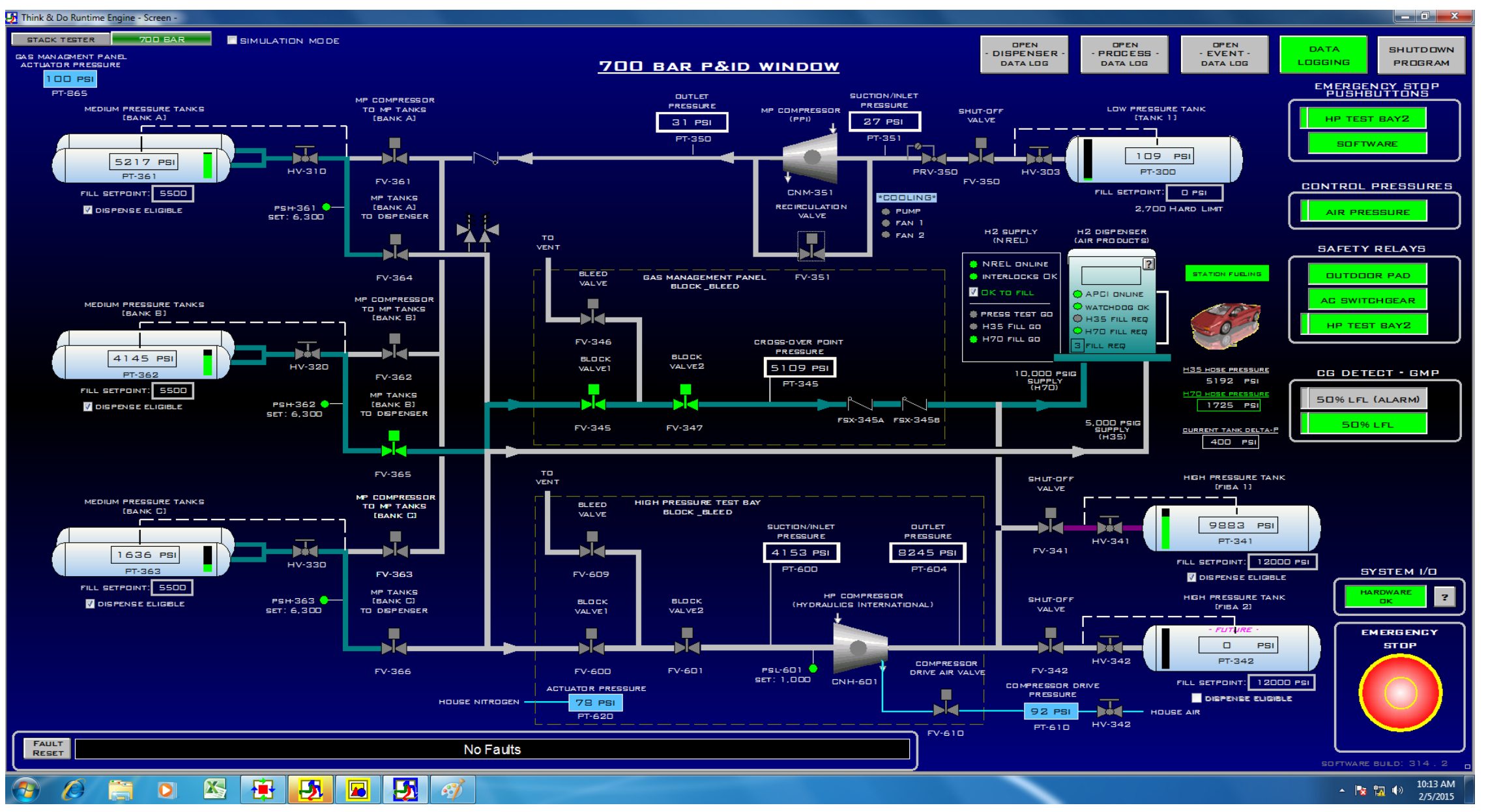

Figure 2. NREL hydrogen fueling facility systems control monitoring screen 


\subsubsection{Hydrogen Production and Storage System}

NREL produces hydrogen through electrolysis using electrolyzer systems located in the adjacent Energy Systems Integration Facility. The hydrogen storage system (Figure 3) has the capacity to fill more than 10 vehicles per day.

The dispenser (Figure 4) can dispense both low-pressure (5,000 psi or 350 bar) and high-pressure $(10,000$ psi or 700 bar) hydrogen. The dispensing system complies with the SAE J2601 fueling protocol for passenger fuel cell electric vehicles, which means that fill time is in the 5-6 minute range.

\subsubsection{Safe Operation}

Multiple levels of protection were designed into the fueling station to reduce the probability that hydrogen is released from the system and to ensure that if a release were to occur it would be detected and the system would shut down. These measures include:

- Emergency stops that would shut down the station in the event of an incident

- Pressure sensors that would detect an out-of-range operating condition that would result in station shut down

- Certification of ASME pressure vessels used to store hydrogen to ensure safe storage

- Physical setback distances for both the hydrogen storage system and the dispenser to protect from accidents caused by unintended releases

- Chemical sensors to detect unintended releases and shut down the system in the event of a release above trigger level

- Barriers to protect the dispenser from physical damage

- Classified electrical components in areas where it is more likely to find hydrogen in the flammable range

- Components that meet standards such as the CGA venting standard and the ASME piping code. 


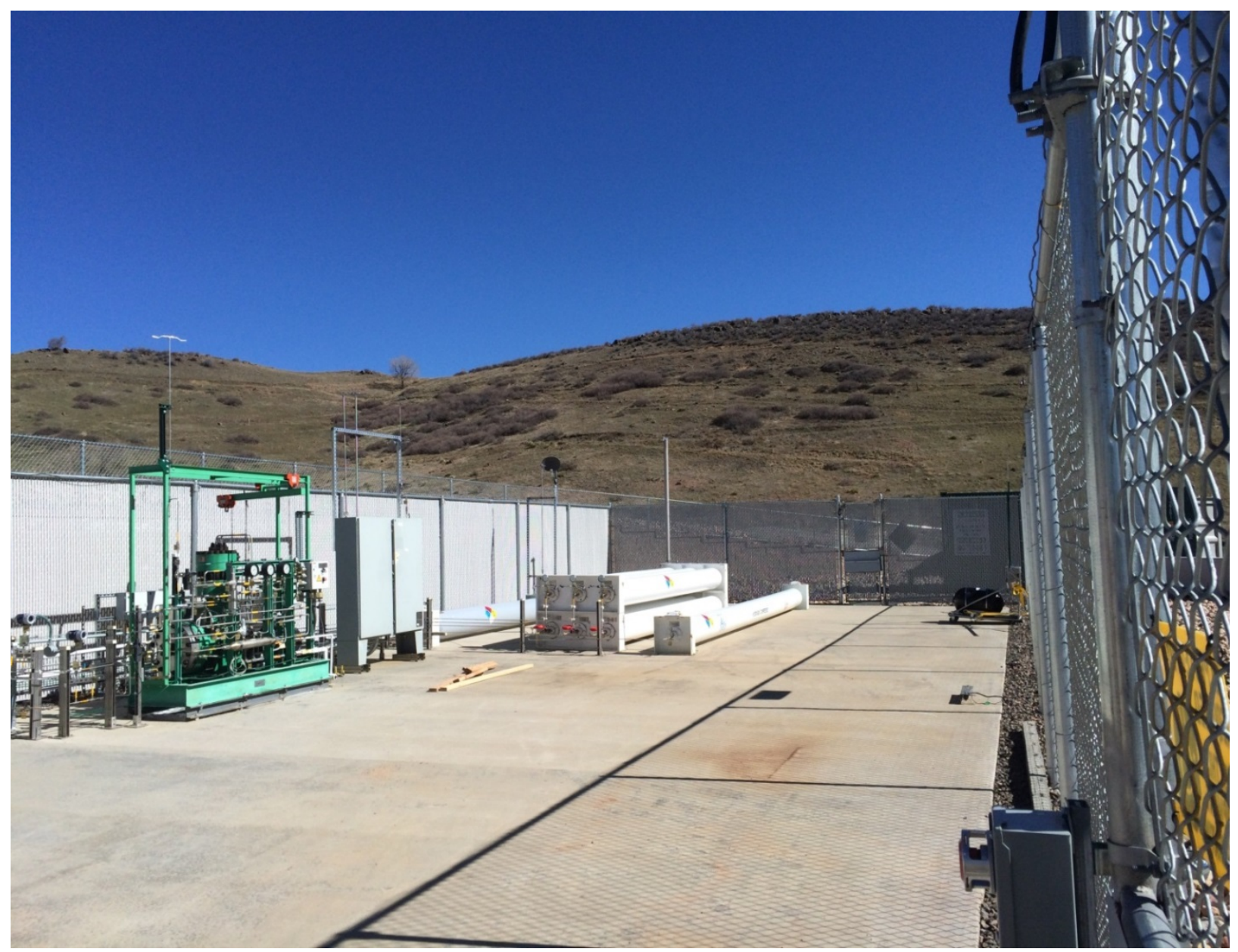

Figure 3. Hydrogen storage

Photo by Carl Rivkin, NREL 


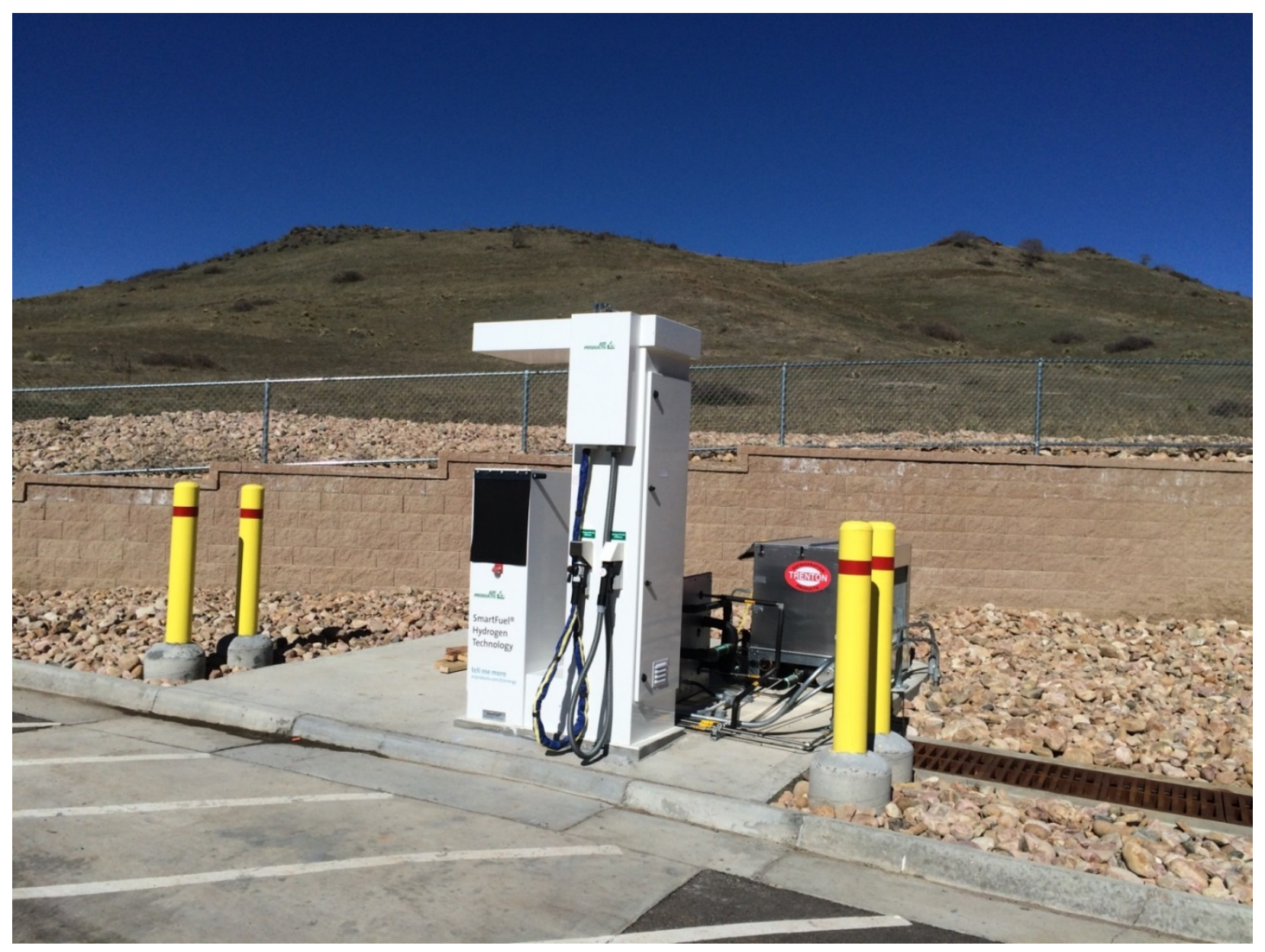

Figure 4. Hydrogen dispenser (note high- and low-pressure fueling hoses)

Photo by Carl Rivkin, NREL 


\subsection{Codes and Standards}

NREL code compliance included the following documents.

\begin{tabular}{|c|c|c|}
\hline Document & Key Sections & Requirements \\
\hline International Fire Code & $\begin{array}{l}2309 \\
50 \\
53 \\
58\end{array}$ & $\begin{array}{l}\text { Hydrogen fueling stations } \\
\text { Hazardous materials } \\
\text { Compressed gases } \\
\text { Flammable gases and cryogenic } \\
\text { fluids }\end{array}$ \\
\hline $\begin{array}{l}\text { NFPA } 2 \text { Hydrogen Technologies } \\
\text { Code }\end{array}$ & $\begin{array}{l}\text { Chapter } 6 \\
\text { Chapter } 7 \\
\text { Chapter } 10\end{array}$ & $\begin{array}{l}\text { General hydrogen safety } \\
\text { requirements } \\
\text { Bulk gaseous hydrogen } \\
\text { (including setback distances for } \\
\text { bulk gaseous hydrogen storage } \\
\text { systems) } \\
\text { Gaseous hydrogen fueling } \\
\text { stations }\end{array}$ \\
\hline $\begin{array}{l}\text { NFPA } 55 \text { Compressed Gas and } \\
\text { Cryogenic Fluids Code }\end{array}$ & $\begin{array}{l}\text { Chapter } 7 \\
\text { Chapter } 10\end{array}$ & $\begin{array}{l}\text { Compressed gases } \\
\text { Bulk hydrogen compressed gas } \\
\text { systems }\end{array}$ \\
\hline $\begin{array}{l}\text { NFPA } 70 \text { National Electrical } \\
\text { Code }\end{array}$ & Article 500 & $\begin{array}{l}\text { Set requirements for classified } \\
\text { electrical areas as defined in } \\
\text { NFPA } 2 \text { around storage and } \\
\text { dispensing systems }\end{array}$ \\
\hline ASME B31.12 & $\begin{array}{l}\text { Hydrogen Pipelines and Piping } \\
\text { Code }\end{array}$ & $\begin{array}{l}\text { Design requirements for } \\
\text { hydrogen piping (will be } \\
\text { referenced in } 2016 \text { edition of } \\
\text { NFPA 2-current NFPA } 2 \\
\text { references precursor document } \\
\text { ASME B31.3) }\end{array}$ \\
\hline $\begin{array}{l}\text { ASME Boiler and Pressure } \\
\text { Vessel Code (BPVC) }\end{array}$ & Chapter XIII & $\begin{array}{l}\text { Design requirements for pressure } \\
\text { vessels (referenced in NFPA 2) } \\
\text { including certification upon } \\
\text { production }\end{array}$ \\
\hline ASME A13.1 & Entire document & $\begin{array}{l}\text { Labeling requirements for } \\
\text { marking piping }\end{array}$ \\
\hline $\begin{array}{l}\text { CGA S-1.3 Pressure Relief for } \\
\text { Stationary Tanks }\end{array}$ & Entire document & Design of PRD for vent system \\
\hline $\begin{array}{l}\text { CGA G-5.5 Hydrogen vent } \\
\text { Systems }\end{array}$ & Entire document & $\begin{array}{l}\text { Design of vent stack including } \\
\text { height, location, and orientation }\end{array}$ \\
\hline SAE J2601 & Entire document & $\begin{array}{l}\text { Fueling protocol to achieve } \\
\text { shortened fill time and prevent } \\
\text { vehicle tank damage }\end{array}$ \\
\hline
\end{tabular}




\section{Hydrogen Basics}

\subsection{Historical and Current Uses of Hydrogen}

For the past 50 years, gaseous hydrogen has been used in large quantities as a feedstock in petroleum refining and the chemical and synthetic fuels industries. Examples include making ammonia for fertilizer and removing sulfur in petroleum refining for products such as reformulated gasoline. Hydrogen also is used in the food processing, semiconductor, glass, and steel industries, as well as by electric utilities as a coolant for large turbine generators.

In 1996, total worldwide consumption of hydrogen was more than 14 trillion cubic feet. Consumption in the United States in 1996 was approximately 3 trillion cubic feet. Almost all of the hydrogen used is captive - that is, consumed at the refinery or chemical plant where it is produced. Nevertheless, a safe and reliable hydrogen distribution network, consisting of liquid hydrogen delivery trucks, gaseous hydrogen tube trailers, and dedicated hydrogen pipelines, has been developed over the years.

\subsection{Hydrogen: Similarities to and Differences from Other Common Fuels}

Gaseous hydrogen has many similarities to conventional fuels now being used routinelygaseous fuels such as methane (i.e., natural gas) and propane and liquid fuels such as gasoline. However, there are some major differences in its properties compared to conventional fuels, as discussed below. In general, hydrogen is neither more nor less inherently hazardous than gasoline, propane, or methane. Consequently, the physical properties of hydrogen and the hazards relating to those properties must be understood in order to design safe hydrogen facilities and hydrogen-powered equipment - particularly for emerging uses of hydrogen. Table 3 lists the physical properties of hydrogen, natural gas, propane, and gasoline.

Table 3. Properties of Hydrogen and Other Fuels

\begin{tabular}{|l|l|l|l|l|}
\hline Property & Gasoline & Propane & Natural Gas & Hydrogen \\
\hline Color & Amber & None & None & None \\
\hline Specific gravity (air = 1) & Liquid & 1.523 & 0.424 & 0.07 \\
\hline Flammability range in air (\%) & 1.4 to 7.6 & 2.1 to 9.5 & 5.3 to 15 & 4 to 74 \\
\hline Ignition energy (millijoules) & 0.20 & 0.26 & 0.29 & 0.02 \\
\hline Flame temperature $\left({ }^{\circ} \mathrm{C}\right)$ & 945 & 1980 & 2,148 & 2,050 \\
\hline Diffusion coefficient $\left(\mathrm{cm}^{3} / \mathrm{s}\right)$ & Liquid & & 0.15 & 0.61 \\
\hline Heat value $(\mathrm{kJ} / \mathrm{kg})$ & 42,847 & 49,920 & 50,020 & 119,972 \\
\hline Energy density $\left(\mathrm{MJ} / \mathrm{nm}^{3}\right)$ & 104.4 & 92.430 & 35.882 & 10.783 \\
\hline
\end{tabular}




\subsubsection{Key Physical Properties}

With respect to safety, the most important properties of hydrogen - compared to gasoline, natural gas, and propane-are as follows:

- Density - Hydrogen is the lightest of all the elements. Hydrogen's low density is the reason for its relatively high buoyancy.

- Buoyancy - At room temperature, gaseous hydrogen has a very low density compared to air and the other fuels. If it were to leak from a container, it would rise more rapidly than methane, propane, or gasoline vapor and quickly disperse.

- Diffusion - Although gas transport from diffusion is much less than gas transport due to buoyancy, hydrogen diffuses through air much more rapidly than other gaseous fuels. This contributes to its rapid dispersion in air.

- Color, odor, taste, and toxicity - Hydrogen, like methane and propane, is a colorless, odorless, tasteless, and nontoxic gas. The lack of color and lack of odor are two reasons why safety sensors are used to detect hydrogen releases.

- Flammability and flame characteristics - The flammability of hydrogen, as a function of concentration level, is greater than that of methane, propane, or gasoline vapor. Unlike the others, however, hydrogen burns with a low-visibility flame in the absence of impurities. In fact, in daylight, a hydrogen fire is almost invisible.

- Ignition energy - Hydrogen can be ignited by a very small amount of energy if its concentration is neither lean nor very rich (and the humidity is low).

- Detonation limits - Hydrogen is detonable over a very wide range of concentrations when confined. However, unlike the other common fuels, it is difficult to detonate when unconfined.

- Flame velocity - Hydrogen has a faster flame speed than many other commonly used fuels. This speed means that an ignited release will produce a jet flame that travels faster than many other commonly used fuels.

- Ignition temperature - Compared to the other fuels, hydrogen has a higher ignition temperature.

\subsubsection{Leak Prevention and Containment}

With respect to safety issues, leak prevention is an important consideration and system design issue. Hydrogen leakage - through paths such as welds, corrosion defects, valves, flanges, diaphragms, gaskets, and various types of seals and fittings - is an important factor in evaluating fire and explosion hazards.

Hydrogen diffuses more rapidly through solid materials than do the other fuel gases. For example, hydrogen will diffuse through the walls of polyethylene pipes at two to three times the energy flow rate of methane. However, the flow rates are so small they rarely produce significant safety concerns.

Hydrogen also can cause a significant deterioration in the mechanical properties of some metals, an effect known as hydrogen embrittlement. The effects of embrittlement and diffusion must be 
considered in design, material selection, and operation in order to minimize the long-term likelihood of leaks as well as catastrophic failure of containment vessels.

If there is a brief leak, hydrogen will rise more rapidly than either methane or propane and will disperse quickly. Hazard levels in unconfined outdoor spaces will be reduced to safe levels in a much shorter time than they will for the other fuels. Propane and gasoline vapors are both heavier than air. Consequently, they will tend to remain at ground level because they disperse more slowly. Hydrogen's rapid dispersion rate is its greatest safety asset.

With a dominant buoyant effect and very high diffusion velocity, hydrogen released from brief leaks mixes with air more rapidly than other fuels do. Indoors, the rapid dispersal of hydrogen may increase or decrease fire hazard, depending upon the size and geometry of confinement. In an open or outdoor area, hydrogen will disperse more quickly than all other fuels do.

Consequently, regardless of whether the application involves use of hydrogen indoors or outdoors, design for safe operations becomes a guiding principle.

\subsubsection{Key Properties of Hydrogen Relating to Fires and Explosions}

The most widely recognized hazard in handling hydrogen is that of unwanted combustion. Characteristics of flammability and combustion include the following:

- Lean and rich flammability limits

- Minimum ignition energy

- Flame temperature.

Hydrogen-air mixtures, when compared to similar fuels, have a wide flammability range and a low minimum ignition energy. This is a disadvantage for the fuel.

There are also advantages to these characteristics. When a fuel ignites, the emissivity influences the total flux of heat radiated. Emissivity is a measure of the efficiency in which a surface emits thermal energy. It is defined as the fraction of energy being emitted relative to that emitted by a thermally black surface (a black body). Hydrogen's low emissivity reduces the heat transferred by radiation to objects near the flame, thus reducing the risks of secondary ignitions and burns. The average emissivity of a flame is a more significant factor than flame temperature when considering thermal radiation damage from fires. Hydrogen flames radiate less heat than natural gas, propane, gasoline, and kerosene flames do, although the flame temperatures of hydrogen and the other common fuels are comparable.

Because of their higher lean limits of flammability, both hydrogen and natural gas are less likely than gasoline or propane to ignite in the case of a small leak discharging into a closed area with a nearby ignition source. However, in the unlikely event of leaking hydrogen accumulating above the lean limit of flammability without ignition, hydrogen would be more likely than other common fuels to ignite because it is more likely to reach a distant ignition source due to its wider flammability range and its lower ignition energy.

With respect to explosions, the maximum burning velocity of hydrogen-air mixtures is about eight times greater than those of natural gas-air and propane-air mixtures. The high burning 
velocity of hydrogen is an indication of its high explosive potential and the difficulty of confining or arresting hydrogen flames and explosions - especially in closed environments. In confined areas, hydrogen storage and use pose the hazards of both combustion and explosionas well as the transition of a combustion event into an explosion. Both processes depend upon the flame velocity, the conditions of confinement, and other factors necessary to accelerate flame velocity. The hazards of combustion and explosion of hydrogen in confined areas can be addressed with proper design, engineering, and operation. Outdoors, an explosion (i.e., a direct detonation) is not likely, except in the rare case of a large hydrogen accumulation and a highenergy ignition source (such as a lightning strike or a chemical explosion). However, a hydrogen cloud is highly unlikely to occur because hydrogen (unlike other conventional fuels) dissipates rapidly in unconfined areas.

\subsection{Special Properties of Liquid Hydrogen}

Many existing and emerging applications of hydrogen involve use of hydrogen in the gaseous form. However, there are important applications that use hydrogen as a liquid. All of the safety considerations and hazards related to gaseous hydrogen also apply to liquid hydrogen because of the ease with which it evaporates. Properties of liquid hydrogen of particular concern with respect to design and safe use include ${ }^{1}$ :

- Low boiling point - Liquid hydrogen (at atmospheric pressure) evaporates at $-423^{\circ} \mathrm{F}$ $\left(-253^{\circ} \mathrm{C}\right)$.

- Ice formation (i.e., internal condensation) - Because of its low temperature, vents and valves in storage vessels might become blocked by accumulations of ice formed from moisture in the air.

- Condensation of air (i.e., external condensation) - Again, because of its low temperature, uninsulated lines containing liquid hydrogen can be cold enough to cause air on the outside of the pipe to liquefy.

- Continuous evaporation - The continuous evaporation (i.e., boiling) of liquid hydrogen in a vessel generates gaseous hydrogen that must be vented safely to prevent pressure buildup.

- Higher density - The slightly higher density of the saturated liquid hydrogen vapor might cause a hydrogen cloud to flow horizontally or vertically upon release if a liquid hydrogen leak were to occur.

\footnotetext{
${ }^{1}$ Source: The Hydrogen Handbook for Building Code and Fire Safety Officials - Current and Innovative Uses of Hydrogen As an Energy Resource and Properties of Hydrogen Compared to Other Fuels, International Code Council, August 2001. See also Handbook of Compressed Gases, 4th edition, Compressed Gas Association, 1999.
} 


\section{Glossary}

The following glossary of terms was excerpted and revised from the DOE Fuel Cell Technologies Office's online glossary at http://energy.gov/eere/fuelcells/glossary. Although not all of these terms are used in this guide, they will likely appear in reference materials on hydrogen technologies and in the associated codes and standards.

adsorption

air

alkaline fuel cell (AFC)

alternating current (AC)

alternative fuel

anode

atmospheric pressure

atom
The adhesion of the molecules of gases, dissolved substances, or liquids in more or less concentrated form, to the surface of solids or liquids with which they are in contact. Commercial adsorbent materials have enormous internal surfaces.

The mixture of oxygen, nitrogen, and other gases, which, with varying amounts of water vapor, forms the atmosphere of the earth.

A type of hydrogen/oxygen fuel cell in which the electrolyte is concentrated potassium hydroxide $(\mathrm{KOH})$, and hydroxide ions $(\mathrm{OH}-)$ are transported from the cathode to the anode. Temperature of operation can vary from $<120^{\circ} \mathrm{C}$ to approximately $250^{\circ} \mathrm{C}$ depending upon electrolyte concentration.

A type of current that flows from positive to negative and from negative to positive in the same conductor.

An alternative to gasoline or diesel fuel that is not produced in a conventional way from crude oil, for example compressed natural gas (CNG), liquefied petroleum gas (LPG), liquefied natural gas (LNG), ethanol, methanol, and hydrogen.

The electrode at which oxidation (a loss of electrons) takes place. For fuel cells, the anode is electrically negative; for the opposite reaction of electrolysis, the anode is electrically positive.

The force exerted by the movement of air in the atmosphere, usually measured in units of force per area. For fuel cells, atmospheric pressure is usually used to describe a system where the only pressure acting on the system is from the atmosphere; no external pressure is applied.

The smallest physical unit of a chemical element that can still retain all the physical and chemical properties of that element. Atoms combine to form molecules, and they themselves contain several kinds of smaller particles. An atom has a dense central core (the nucleus) consisting of positively charged particles (protons) and uncharged particles (neutrons). Negatively charged particles (electrons) are scattered in a relatively large space around this nucleus and move about it in orbital patterns at extremely high speeds. An atom contains the same number of protons as electrons and thus is electrically neutral (uncharged) and stable under most conditions. 
British thermal unit (Btu)

carbon (C)

carbon dioxide $\left(\mathrm{CO}_{2}\right)$

carbon monoxide (CO)

catalyst

catalyst poisoning

cathode
The mean British thermal unit is $1 / 180$ of the heat required to raise the temperature of one pound $(1 \mathrm{lb})$ of water from $32^{\circ} \mathrm{F}$ to $212^{\circ} \mathrm{F}$ at a constant atmospheric pressure. It is about equal to the quantity of heat required to raise one pound $(1 \mathrm{lb})$ of water $1^{\circ} \mathrm{F}$.

An atom and primary constituent of hydrocarbon fuels. Carbon is routinely left as a black deposit on engine parts such as pistons, rings, and valves by the combustion of fuel.

Carbon dioxide is a colorless, odorless, noncombustible gas that is slightly more than 1.5 times as dense as air and becomes a solid (dry ice) below $-78.5^{\circ} \mathrm{C}$. It is present in the atmosphere as a result of the decay of organic material and the respiration of living organisms, and it represents about $0.033 \%$ of the air. Carbon dioxide is produced by the burning of wood, coal, coke, oil, natural gas, or other fuels containing carbon, by the action of an acid on a carbonate, or naturally from springs and wells. Carbon dioxide is a greenhouse gas and is a major contributor to the greenhouse effect.

A pollutant from engine exhaust that is a colorless, odorless, tasteless, poisonous gas that results from incomplete combustion of carbon with oxygen.

A chemical substance that increases the rate of a reaction without being consumed; after the reaction it can potentially be recovered from the reaction mixture chemically unchanged. The catalyst lowers the activation energy required, allowing the reaction to proceed more quickly or at a lower temperature. In a fuel cell, the catalyst facilitates the reaction of oxygen and hydrogen. It is usually made of platinum powder very thinly coated onto carbon paper or cloth. The catalyst is rough and porous so that the maximum surface area of the platinum can be exposed to the hydrogen or oxygen. The platinum-coated side of the catalyst faces the membrane in the fuel cell.

The process of impurities binding to a fuel cell's catalyst, lowering the catalyst's ability to facilitate the desired chemical reaction. See also "fuel cell poisoning".

The electrode at which reduction (a gain of electrons) occurs. In a fuel cell, the cathode has channels etched into it that distribute the oxygen to the surface of the catalyst. It also conducts the electrons back from the external circuit to the catalyst, where they can recombine with the hydrogen ions and oxygen to form water. 
Celsius

combustion

compressed hydrogen gas (CHG)

compressed natural gas $(\mathrm{CNG})$

compressor

density

dispersion

electrode

electrolysis

electrolyte

emission standards

energy

Fahrenheit
Metric temperature scale and unit of temperature $\left({ }^{\circ} \mathrm{C}\right)$. Named for Swedish astronomer Anders Celsius (1701-1744) although the thermometer first advocated by him in 1743 had $100^{\circ}$ as the freezing point of water, and $0^{\circ}$ as the boiling point, the reverse of the modern Celsius scale. Also called the Centigrade scale (Latin for "hundred degrees").

Burning, fire produced by the proper combination of fuel, heat, and oxygen. In the engine, the rapid burning of the air-fuel mixture that occurs in the combustion chamber.

Compressed hydrogen gas is hydrogen compressed to a high pressure and stored at ambient temperature.

Mixtures of hydrocarbon gases and vapors, consisting principally of methane in gaseous form that has been compressed for use as a vehicular fuel. (NFPA 52)

A device used for increasing the pressure and density of gas.

The amount of mass in a unit volume. Density varies with temperature and pressure.

The spatial property of being scattered about over an area or volume.

A conductor through which electrons enter or leave an electrolyte. Batteries and fuel cells have a negative electrode (the anode) and a positive electrode (the cathode).

The process where an electric current is passed through an electrolytic solution or other appropriate medium, causing a chemical reaction. The process of driving a redox reaction in the reverse direction by passage of an electric current through the reaction mixture.

A substance that conducts charged ions from one electrode to the other inside a fuel cell.

Regulatory standards that govern the amount of a given pollutant that can be discharged into the air from a given source.

The quantity of work a system or substance is capable of doing, usually measured in British thermal units (Btu) or Joules (J).

Temperature scale and unit of temperature $\left({ }^{\circ} \mathrm{F}\right)$. Named for German physicist Gabriel Daniel Fahrenheit (1686-1736) who was the first to use mercury as a thermometric fluid in 1714 . 
flammability

flashpoint

flexible fuel vehicle

fuel

fuel cell

fuel cell poisoning

fuel cell stack

fuel processor

gas

gas diffusion
The flammability range of a gas is defined in terms of its lower flammability limit (LFL) and its upper flammability limit (UFL). Between the two limits is the flammable range in which the gas and air are in the right proportions to burn when ignited. Below the lower flammability limit there is not enough fuel to burn. Above the higher flammability limit there is not enough air to support combustion.

The lowest temperature under very specific conditions at which a substance will begin to burn.

A vehicle that can operate on a wide range of fuel blends (e.g., blends of gasoline and alcohol) that can be put in the same fuel tank.

A material used to create heat or power through chemical conversion in processes such as burning or electrochemistry.

A device that uses hydrogen and oxygen to create electricity through an electrochemical process.

The lowering of a fuel cell's efficiency due to impurities in the fuel binding to the catalyst.

Individual fuel cells connected in series. Fuel cells are stacked to increase electrical current.

Device used to extract the hydrogen from fuels, such as natural gas, propane, gasoline, methanol, and ethanol, for use in fuel cells.

Fuel gas, such as natural gas, undiluted liquefied petroleum gases (vapor phase only), liquefied petroleum gas-air mixtures, or mixtures of these gases. Liquefied petroleum gases (LPG), as used in this standard, shall mean and include any material that is composed predominantly of any of the following hydrocarbons or mixtures of them: propane, propylene, butanes (normal butane or isobutane), and butylenes.

LP gas-air mixture - Liquefied petroleum gases distributed at relatively low pressures and normal atmospheric temperatures that have been diluted with air to produce desired heating value and utilization characteristics.

Natural gas - Mixtures of hydrocarbon gases and vapors consisting principally of methane $\left(\mathrm{CH}_{4}\right)$ in gaseous form.

Mixing of two gases caused by random molecular motions. Gases diffuse very quickly; liquids diffuse much more slowly, and solids diffuse at very slow (but often measurable) rates. Molecular collisions make diffusion slower in liquids and solids. 
hydrocarbon (HC) An organic compound containing only carbon and hydrogen, usually derived from fossil fuels such as petroleum, natural gas, and coal: an agent in the formation of photochemical smog.

hydrogen $\left(\mathrm{H}_{2}\right) \quad$ The simplest and lightest element in the universe, which exists as a gas except at low cryogenic temperatures. Hydrogen gas is a colorless, odorless, and highly flammable gas when mixed with oxygen over a wide range of concentrations. Hydrogen forms water when combusted or when otherwise joined with air, as within a fuel cell.

hydrogen-rich fuel A fuel that contains a significant amount of hydrogen, such as gasoline, diesel fuel, methanol $\left(\mathrm{CH}_{3} \mathrm{OH}\right)$, ethanol $\left(\mathrm{CH}_{3} \mathrm{CH}_{2} \mathrm{OH}\right)$, natural gas, and coal.

kilogram $(\mathrm{kg})$

Metric unit of weight or mass, equal to approximately $2.2 \mathrm{lb}$. Related units are the milligram $(\mathrm{mg})$ at 1,000 per $\mathrm{kg}$, and the metric tonne at $1,000 \mathrm{~kg}$.

kilowatt (kw)

A unit of power equal to about $1.34 \mathrm{hp}$ or 1,000 watts. The watt is named for James Watt, Scottish engineer (1736-1819), a pioneer in steam engine design.

liquefied hydrogen $\left(\mathrm{LH}_{2}\right)$

liquefied natural gas (LNG)

liquefied petroleum gas (LPG)

meter $(\mathrm{m})$

methane $\left(\mathrm{CH}_{4}\right) \quad$ See "natural gas". pressure.
Hydrogen in liquid form. Hydrogen can exist in a liquid state, but only at extremely cold temperatures. Liquid hydrogen typically has to be stored at $-253^{\circ} \mathrm{C}\left(-423^{\circ} \mathrm{F}\right)$. The temperature requirements for liquid hydrogen storage necessitate expending energy to compress and chill the hydrogen into its liquid state. The cooling and compressing process requires energy, resulting in a net loss of about $30 \%$ of the energy that the liquid hydrogen is storing. The storage tanks are insulated, to preserve temperature, and reinforced to store the liquid hydrogen under

Natural gas in liquid form. Natural gas is a liquid at $-162^{\circ} \mathrm{C}\left(-259^{\circ} \mathrm{F}\right)$ at ambient pressure.

Any material that is composed predominantly of any of the following hydrocarbons or mixtures of hydrocarbons: propane, propylene, normal butane, isobutylene, and butylenes.

Basic metric unit of length equal to 3.28 feet, 1.09 yards, or 39.37 inches. Related units are the decimeter $(\mathrm{dm})$ at 10 per meter, the centimeter $(\mathrm{cm})$ at 100 per meter, the millimeter $(\mathrm{mm})$ at 1,000 per meter, and the kilometer $(\mathrm{km})$ at 1,000 meters. 
methanol $\left(\mathrm{CH}_{3} \mathrm{OH}\right)$

natural gas

nitrogen $\left(\mathrm{N}_{2}\right)$

oxygen $\left(\mathrm{O}_{2}\right)$

phosphoric acid fuel cell (PAFC)

polymer electrolyte membrane (PEM)

polymer electrolyte membrane fuel cell (PEMFC or PEFC)

propane $\left(\mathrm{C}_{3} \mathrm{H}_{8}\right)$

reformer

reforming

reformulated gasoline
Methyl alcohol is the simplest of the alcohols. It has been used, together with some of the higher alcohols, as a high-octane gasoline component and is a useful automotive fuel in its own right.

A naturally occurring gaseous mixture of simple hydrocarbon components (primarily methane) used as a fuel.

A colorless, tasteless, odorless gas that constitutes $78 \%$ of the atmosphere by volume and is a part of all living tissues.

A colorless, tasteless, odorless, gaseous element that makes up about $21 \%$ of air. Oxygen is capable of combining rapidly with all elements (except inert gases) in the oxidation process called burning (combustion). Oxygen combines very slowly with many metals in the oxidation process called rusting.

A type of fuel cell in which the electrolyte consists of concentrated phosphoric acid $\left(\mathrm{H}_{3} \mathrm{PO}_{4}\right)$ and protons $\left(\mathrm{H}^{+}\right)$that are transported from the anode to the cathode. The operating temperature range is generally $160^{\circ}-220^{\circ} \mathrm{C}$.

A solid membrane, similar in consistency to thick plastic wrap, used as an electrolyte in fuel cells. The membrane allows positively charged ions to pass through it but blocks electrons. See also "polymer electrolyte membrane fuel cell".

A type of acid-based fuel cell in which the transport of protons $\left(\mathrm{H}^{+}\right)$ from the anode to the cathode is through a solid, aqueous membrane impregnated with an appropriate acid. The electrolyte is called a polymer electrolyte membrane (PEM). The fuel cells typically run at low temperatures $\left(<100^{\circ} \mathrm{C}\right)$.

Hydrocarbon fuel that has been processed into hydrogen and other products for use in fuel cells.

Device used to extract the hydrogen from fuels, such as natural gas, propane, gasoline, methanol, and ethanol, for use in fuel cells.

A chemical process that reacts hydrogen-containing fuels in the presence of steam, oxygen, or both into a hydrogen-rich gas stream.

Gasoline that is blended so that, on average, it significantly reduces volatile organic compounds and air toxics emissions relative to conventional gasolines. 
solid oxide fuel cell (SOFC)

stack

steam reforming

technology

validation

temperature

water $\left(\mathrm{H}_{2} \mathrm{O}\right)$
A type of fuel cell in which the electrolyte is a solid, nonporous metal oxide, typically zirconium oxide $\left(\mathrm{ZrO}_{2}\right)$ doped with $\mathrm{Y}_{2} \mathrm{O}_{3}$, and $\mathrm{O}_{2}$ - is transported from the cathode to the anode. Any carbon monoxide (CO) in the reformate gas is oxidized to carbon dioxide $\left(\mathrm{CO}_{2}\right)$ at the node. Temperatures of operation are typically $800^{\circ}-1,000^{\circ} \mathrm{C}$.

See "fuel cell stack".

The process for reacting a hydrocarbon fuel, such as natural gas, in the presence of steam to form hydrogen as a product. This is a common method of bulk hydrogen generation.

Confirming that technical targets for a given technology have been met.

A measure of thermal content.

A colorless, transparent, odorless, tasteless liquid compound of hydrogen and oxygen. The liquid form of steam and ice. Fresh water at atmospheric pressure is used as a standard for describing the relative density of liquids, the standard for liquid capacity, and the standard for fluid flow. The melting and boiling points of water are the basis for the Celsius temperature system. Water is the only byproduct of the combination of hydrogen and oxygen, and is produced during the burning of any hydrocarbon. Water is the only substance that expands on freezing as well as by heating, and has a maximum density at $4^{\circ} \mathrm{C}$. 